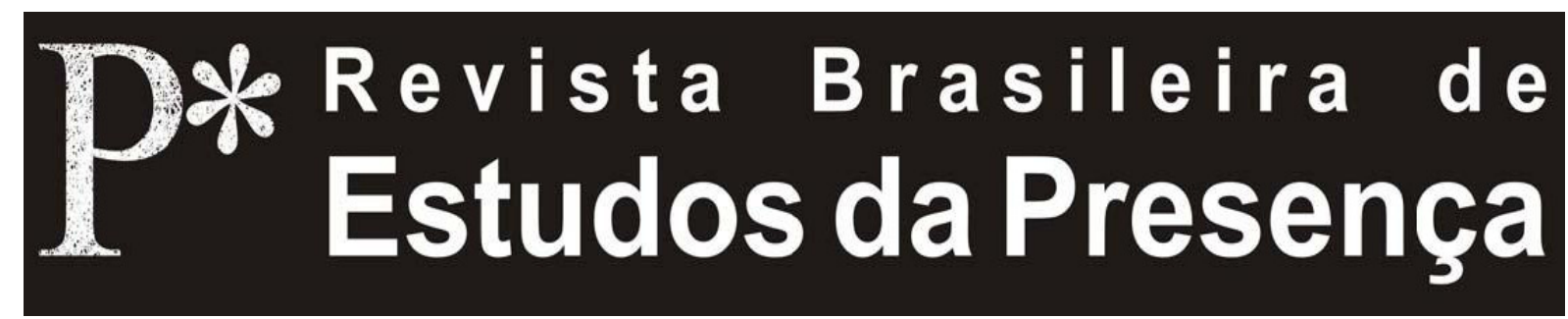

DOI - http://dx.doi.org/10.1590/2237-266038117

ISSN 2237-2660

\title{
Marguerite Duras/Claude Régy: L'Amante Anglaise, gênese de uma escrita, gestação de um teatro
}

\author{
Almuth Grésillon \\ Marie-Madeleine Mervant-Roux \\ Centre National de la Recherche Scientifique - CNRS, Paris, França
}

RESUMO - Marguerite Duras/Claude Régy: L'Amante Anglaise, gênese de uma escrita, gestaçáo de um teatro ${ }^{1}$ - Este artigo tem como objetivo a gênese da primeira encenaçáo de L'Amante Anglaise de Margarite Duras, por Claude Régy, uma feliz gênese, realizada a partir da influência recíproca entre a dramaturgia e a cena. Afronta-se, sem uma resposta exata, uma questão teórica importante para a crítica genética aplicada ao teatro: a obra estudada seria o texto dramático ou o espetáculo? Dependendo do acento na primeira ou na segunda resposta, o eixo organizador do dossiê genético pode ser o trabalho de escritura do autor e todas as encenaçóes de L'Amante Anglaise, formando um conjunto teoricamente unificado; ou, os registros do diretor e o conjunto de suas criaçóes. Este estudo explora uma terceira possibilidade, estipulando um necessário cruzamento entre as duas hipóteses.

Palavras-chave: Gênese. Texto. Cena. Produção Teatral. Inacabamento.

ABSTRACT - Marguerite Duras/Claude Régy: L'Amante Anglaise, the genesis of a text, the gestation of a theatre - This article focuses on the genesis of the first staging of Margerite Duras's L'Amante Anglaise, by Claude Régy, a well succeeded genesis, carried out based on the interplay between dramaturgy and the stage. Without any satisfying answer, we are facing an important theoretical issue of genetic criticism applied to theatre: is the work a dramatic text or a spectacle? Depending on the stress on the first or on the second answer, the organizing axis of the genetic dossier can be the author's writing and all stagings of L'Amante Anglaise, forming a theoretically unified set; or the director's notes and all of his creations. This study explores a third possibility, stipulating the indispensable intersection between both hypotheses.

Keywords: Genesis. Text. Scene. Theatrical Production. Unfinishedness.

RÉSUMÉ - Marguerite Duras/Claude Régy: L'Amante Anglaise, genèse d'une écriture, gésine d'un théâtre - L'article prend pour objet la genèse de la première mise en scène de L'Amante Anglaise de Marguerite Duras due à Claude Régy, une genèse heureuse, du fait de l'influence réciproque entre l'écriture et la scène. Il affronte, sans la résoudre, une question théorique majeure de la critique génétique appliquée au théâtre: l'œuvre à étudier est-elle le texte dramatique, ou bien le spectacle? Selon que l'on privilégie la première réponse ou la seconde, l'axe organisateur du dossier génétique est le travail scriptural de l'auteur, toutes les mises en scène de L'Amante anglaise formant alors un ensemble théoriquement unifié, ou bien celui du metteur en scène, l'ensemble cohérent étant constitué par toutes les créations de ce dernier. L'étude explore une troisième voie en stipulant un nécessaire croisement des deux hypothèses.

Mots-clés: Genèse. Texte. Scène. Production. Inachèvement. 
'Tu ainda tens teu exemplar?' me perguntou um dia Marguerite, fazendo alusão a esse borrão magnífico: trechos escritos por ela entre as linhas impressas, passagens riscadas, retomadas, indicaçóes adicionadas pelo assistente, por mim, inscrições em todas as direçóes [...] Páginas cobertas de signos de todas as cores, parecia quase uma pintura [...] Páginas quase indecifráveis, com tirinhas de papel coladas, saindo por todos os lados e as inserçóes manuscritas ou datilografadas. Uma frase é retirada, um trecho colocado antes, outro depois [...] Eu me emociono muito ao folhar esse objeto, um testemunho insubstituível (Michael Lonsdale, Visites, p. 187).

O documento ao qual Michael Lonsdale dedica as linhas citadas acima é, no início, seu exemplar pessoal do romance L'Amante Anglaise [A Amante Inglesa] (1967), no qual vieram se inscrever as modificaçóes, cortes e reescrituras decididas durante os ensaios do espetáculo homônimo, no outono de 1968. A descoberta desse "borrão magnífico"2 (imagem I) nos incitou a trabalhar sobre L'Amante Anglaise, em vez de outras peças mais conhecidas de Marguerite Duras. Ele simboliza na sua própria beleza plástica - "quase uma pintura" - a imensa complexidade das gêneses teatrais e nossa ambiçáo de levá-la em conta: conceber de antemáo como dialéticas as relaçóes entre gênese textual e gênese cênica, conceber os ensaios como o ponto de encontro dessas relaçóes, conceber o espetáculo como o resultado de múltiplas intervençóes (engajando o autor e o diretor, mas também os atores - e todos os outros artistas), observar todos os traços, heterogêneos e multiformes (textos, croquis, esquemas técnicos, fotografias) do espetáculo.

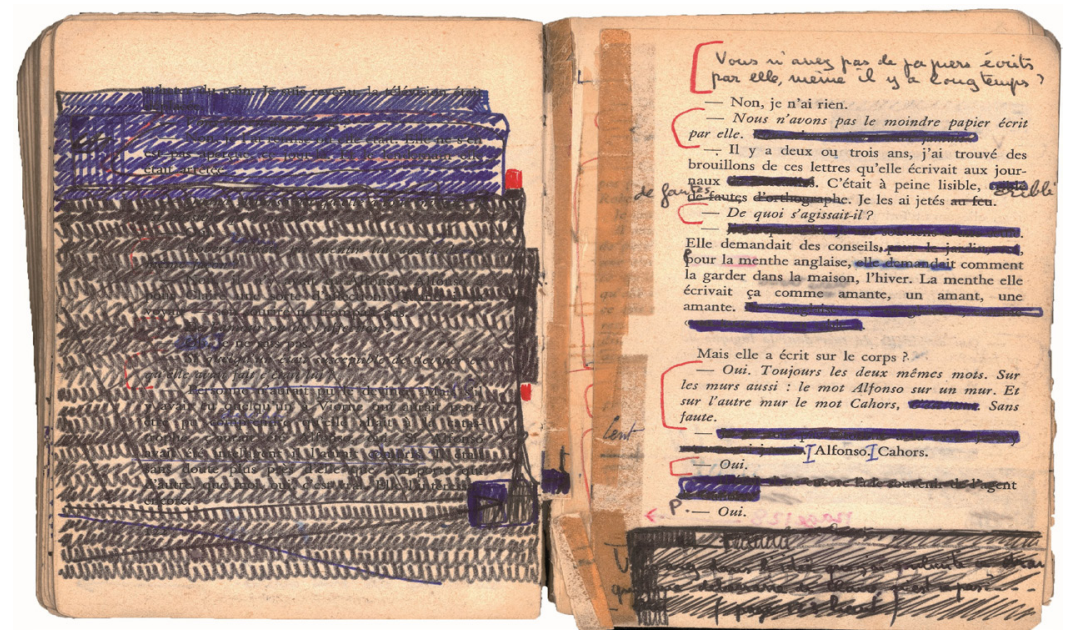

Imagem 1 - L'Amante Anglaise, de Marguerite Duras, direção de Claude Régy. Duas páginas do "borrão magnífico" de Michael Lonsdale, tiradas das páginas 122 e 124 do romance (Paris, Gallimard, primeira edição, 1967). As falas marcadas com colchetes vermelhos são as do ator (Col. pessoal de M. Lonsdale). 


\section{Observaçóes Introdutórias}

Resumo da peça. L'Amante Anglaise possui três personagens: uma figura anônima chamada o interrogador, Pierre Lannes e sua esposa Claire. $\mathrm{Na}$ abertura, um anúncio gravado lembra um fato real ocorrido em dezembro de 1949: os restos do corpo de uma mulher exceto a cabeça - foram encontrados em trens em diversos lugares na França. A reunião das informaçóes ferroviárias permitiu localizar o viaduto do qual eles tinham sido jogados (Viorne, no departamento da Essonne) e identificar o autor do crime: Claire Lannes matou Marie-Thérèse Bousquet, uma prima surda e muda que vivia há muitos anos com o casal. A peça intercala os diálogos do interrogador com Pierre Lannes e com Claire Lannes. Às duas questôes: onde está a cabeça? qual é o motivo do crime? nenhuma resposta será dada.

\section{Nosso Objeto: a encenação de Claude Régy}

Se a criação de L'Amante Anglaise, em dezembro de 1968, no Théâtre du Palais de Chaillot, sala Gémier, é vista hoje como um evento marcante na história do teatro francês contemporâneo, é porque, antes de tudo, ela foi importante para os próprios artistas. Para Marguerite Duras, falou-se de uma revolução entre a peça $O s$ viadutos da Seine-et-Oise, publicada em 1960, montada por Claude Régy em 1963, e L'Amante Anglaise, apresentada normalmente como uma nova versão de Viaducs, mas na realidade oriunda de um processo de reescrita bem mais complexo e que o presente estudo se propóe a reconstruir. Quanto a Régy, o espetáculo, de certa maneira antiespetacular do inverno de 1968-1969, representou uma virada no seu itinerário pessoal - foi seu verdadeiro início teatral, insiste ele frequentemente ${ }^{3}$. Única realização entre as setenta assinadas por ele a ter sido retomada $(1971,1976,1982-83,1989)$, sua memória é doravante literalmente inscrita no texto da peça, pois Marguerite Duras, em 1991, para a edição que serve hoje de referência ${ }^{4}$, fixou em rubricas prescritivas as decisôes cenográficas essenciais de 1968.

Tomar por objeto a gênese dessa primeira encenação foi escolher estudar um processo genético bem sucedido, pelo fato da influência determinante e recíproca entre a escrita e a cena: o texto entáo inacabado suscitou a escolha de um certo espaço cenográfico, que agiu por sua vez sobre o trabalho da escritora. Foi, também, uma maneira de solucionar, sem resolver completamente, uma importante questáo 
teórica da crítica genética aplicada ao teatro: a obra estudada é o texto dramático ou o espetáculo? Ao privilegiar-se a primeira resposta, o eixo organizador do dossiê genético é o trabalho redacional da autora, no caso Marguerite Duras, e todas as encenaçóes de L’Amante Anglaise formariam assim um conjunto teoricamente unificado. Ao optar-se pela segunda resposta, o eixo organizador seria o trabalho do encenador que, por sua vez, formaria um conjunto coerente constituído, dentro dessa perspectiva, por todas as suas criaçóes. Nosso estudo, levando em conta ao mesmo tempo texto e cena, explora uma terceira via, estipulando o cruzamento imperativo das duas hipóteses. Essa escolha inicial não impediu um certo desequilíbrio a favor do texto, devido à tradiçáo cultural geral dos arquivos e à dificuldade específica das gêneses teatrais: objetivamente, é mais fácil reunir traços do trabalho redacional do que do trabalho ligado ao palco.

\section{Uma Gênese Ricamente Documentada}

No entanto, no caso de L'Amante Anglaise, os documentos são numerosos. Os vestígios do trabalho dos diferentes artistas estáo dispersos em arquivos públicos e privados: a) um primeiro conjunto se encontra nos arquivos Duras do IMEC 5 . Ele contém rascunhos de uma peça inacabada, tentativa não concluída de revisão dos Viadutos, as etapas redacionais e as versóes corrigidas de um romance, o texto impresso do romance e, também, uma série heterogênea de documentos oriundos do contato direto do encenador com os atores; b) os documentos relativos à realizaçáo cênica - estudos, croquis, planos técnicos, orçamentos e notas do cenógrafo, recibos, plannin$g s$, fotografias dos ensaios, música do espetáculo, plano de locaçáo, programas, etc. - pertencem ou aos arquivos Jacques Le Marquet, ou à coleçâo do Théâtre du Palais de Chaillot (conservados na BnF [Bibliothèque Nationale de France], departamento de Artes do espetáculo); c) existem alguns arquivos sonoros na Rádio France e na Inathèque $^{6}$; ) os textos de Madeleine Renaud sáo conservados nos arquivos Renaud-Barrault (BnF, dpto. de Artes do espetáculo).

Tivemos acesso, também, aos arquivos privados de Michael Lonsdale e Jean Mascolo ${ }^{7}$, filho de Marguerite Duras e Dionys Mascolo, exploramos entrevistas já realizadas ${ }^{8}$ e encontramos, pessoalmente, alguns artistas e testemunhas?.

Graças à diversidade dos arquivos e depoimentos, foi possível reconstituir certos aspectos do que se chama às vezes escrita por diversas 
máos do teatro e que engaja, na realidade, o corpo inteiro - a voz, a escuta, o olhar, os braços, o quadril, as pernas, os pés ${ }^{10}$. Infelizmente, certos documentos não foram encontrados: o texto do encenador, a gravação sonora do espetáculo provavelmente efetuada no $\mathrm{TNP}^{11} \mathrm{e}$, surpreendentemente, a quase totalidade dos documentos radiofônicos. Mas, a reunião desses documentos preciosos que estão faltando ainda não nos permitiria apreender de maneira exaustiva os processos de criaçáo de uma arte profundamente enraizada no social e cujas obras são eventos públicos, na qual cada acontecimento é único e efêmero.

\section{Um Teatro Pronto a se Reinventar: o contexto dos anos 1960}

Os anos 1960 são, para Marguerite Duras, um período de experimentação de inúmeras formas: ela escreve suas primeiras peças (Le Square, tirado do romance homônimo, 1956), roteiros cinematográficos (Moderato Cantábile, 1958; Hiroshima mon Amour, 1959), um romance (Le Ravissement de Lol V. Stein, 1964), diversas adaptaçôes para o teatro (La Bête dans la Jungle, 1962) e ela trabalha para a rádio. Assim, diante do fato real de 1949, descoberto graças às crônicas judiciárias do jornal Le Monde e que forneceu o fio narrativo de L'Amante Anglaise, ela se interessa por diversos campos de desenvolvimento possíveis: o cinema (observa-se um projeto de filme a partir de 1963 com a atriz Loleh Bellon; e dois outros, em 1971 e 1982), a rádio (uma peça radiofônica com Michel Bouquet, François Chaumette e, novamente, Loleh Bellon, gravada em 1967 e que nunca foi ao ar; um outro projeto fracassara em 1973) e, enfim, alternando um e outro, o teatro e a literatura.

Claude Régy, quanto a ele, procura seu caminho. Quando ele monta Os Viadutos, em 1963, ele ainda é um debutante audacioso e promissor: ele montou em francês Dona Rosita de Garcia Lorca (1952), La Vie que je t’ai donnée de Pirandello (1954), Penthésilée de Kleist (1955). Entre 1965 e 1968, ele monta em uma rápida sucessão as peças dos jovens ingleses rebeldes (Saunders, Osborne, Stoppard) e permite a descoberta na França da obra de Pinter, montando de maneira brilhante uma escrita contemporânea desconhecida e desconcertante para o público. Se sua direção de atores é inovadora, o cenário permanece de Boulevard. Em 1967, ele se encontra a meio caminho de uma transformação radical na sua prática teatral. 


\section{Movimentos Genéticos}

\section{3-1967: metamorfoses textuais (entre teatro e romance)}

Depois do término das apresentaçóes de Viaducs (direção de Claude Régy), Duras, insatisfeita, retoma o trabalho sobre o seu texto. Quase duzentas folhas de rascunhos (conservadas no IMEC) comprovam essa tentativa de reescrita teatral marcada, entre outras coisas, por modificaçóes de nomes próprios, pela invenção do misterioso "J", transformado em "E. F.", espécie de prefiguração do futuro Interrogador, a aparição de inúmeras rubricas, notadamente de inúmeros "silêncio" (Imagem 2). Ao mesmo tempo, aparecem sinais de hesitação quanto ao gênero teatral; tudo se passa como se Duras oscilasse entre os Atos de uma peça e os Capitulos de um romance, ou até mesmo as cenas de um filme. Lê-se, assim, nessa observação:

Se esse texto fosse representado na tela no teatro, a passagem do capítulo I ao capítulo II deveria ser feita da seguinte maneira: a luz baixaria nos últimos minutos do diálogo, até o blackout. Depois, pouco a pouco, apareceria o café de Bill com os personagens enumerados por Marcel, paralisados [...] (Imagem 3).

Essa indecisão vai dar origem a uma pilha de cento e quarenta e duas folhas datilografadas de texto seguida de um "romance dialogado", dotado pela primeira vez do título L’Amante Anglaise. Algumas correçóes manuscritas dáo conta dessa fase redacional do romance. Quando Duras reutiliza as velhas folhas, ela risca os fragmentos que se tornaram obsoletos; desaparecem assim os nomes que no texto de teatro indicam a troca de falas, e, para ter certeza dessa mudança capital, Duras acrescenta no início de um capítulo: "Os nomes: Claire e E. F. devem ser suprimidos" (Imagem 4). Essa fase de elaboração textual vem seguida de três jogos sucessivos de versóes corrigidas, datados de dezembro de 1966 e de janeiro de 1967. Ao observar-se o peso das correçóes do autor nessa fase final da elaboração textual, dá-se conta de a que ponto, para Duras, a escrita é um processo sem fim. Ela muda ainda nas versões todos os nomes próprios (Imagem 5); ela modifica frequentemente os tempos verbais, acrescenta inúmeras precisões tipográficas (Imagem 6), e, quando não há mais espaço para suas correçóes manuscritas, ela datilografa de novo todo um parágrafo e faz uma colagem (Imagem 7).

Finalmente, o romance é publicado em fevereiro de 1967. Duras levou quatro anos para transformar a peça Les Viaducs no romance chamado L'Amante Anglaise. 


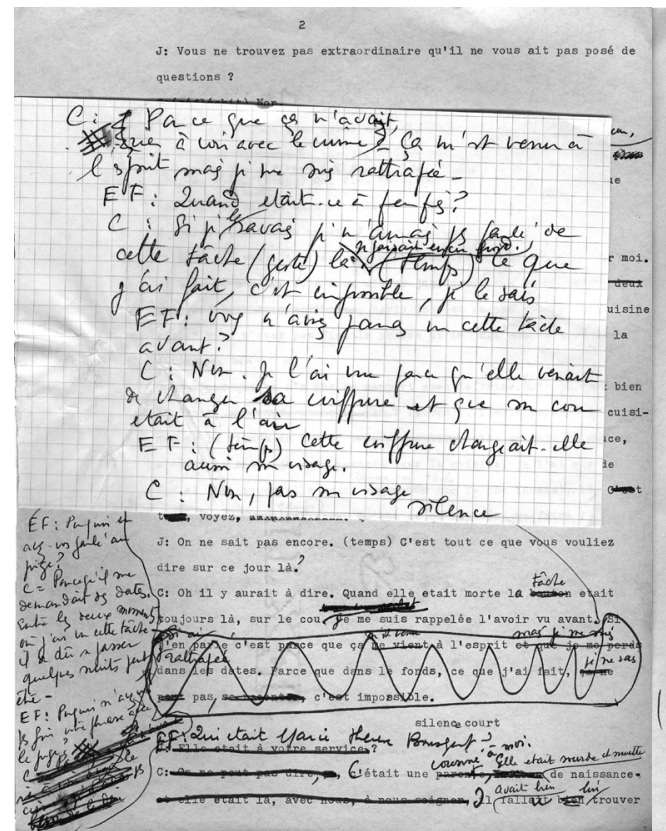

Imagem 2 - Tentativa de reescrita teatral de Viadutos. Folha datilografada número 2 , retrabalhada a máo e completada por um papel colado por Duras. (IMEC 7.8, $\mathrm{f}^{\circ} 2$ ).

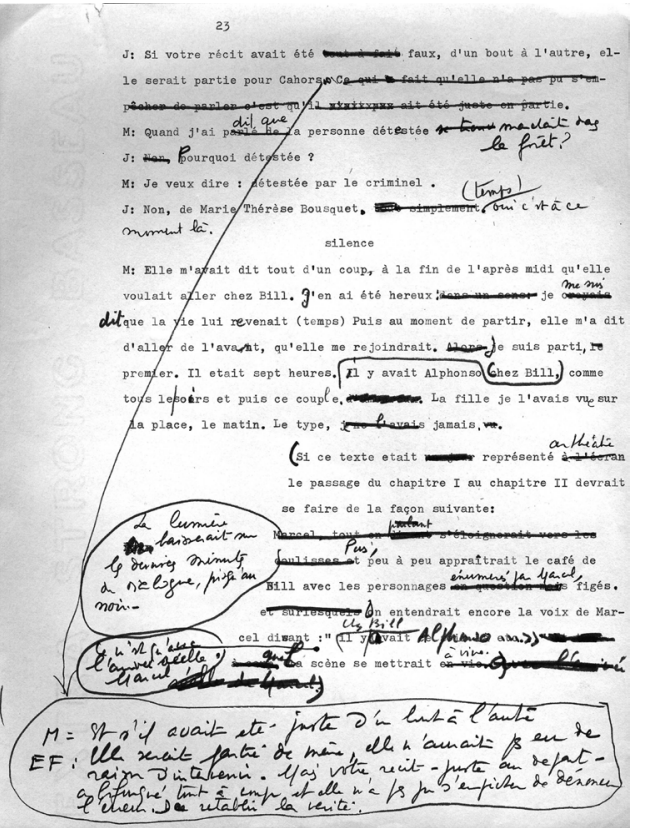

Imagem 3 - Mesma campanha de reescrita. (IMEC 7.8, f ${ }^{\circ} 23$ ).

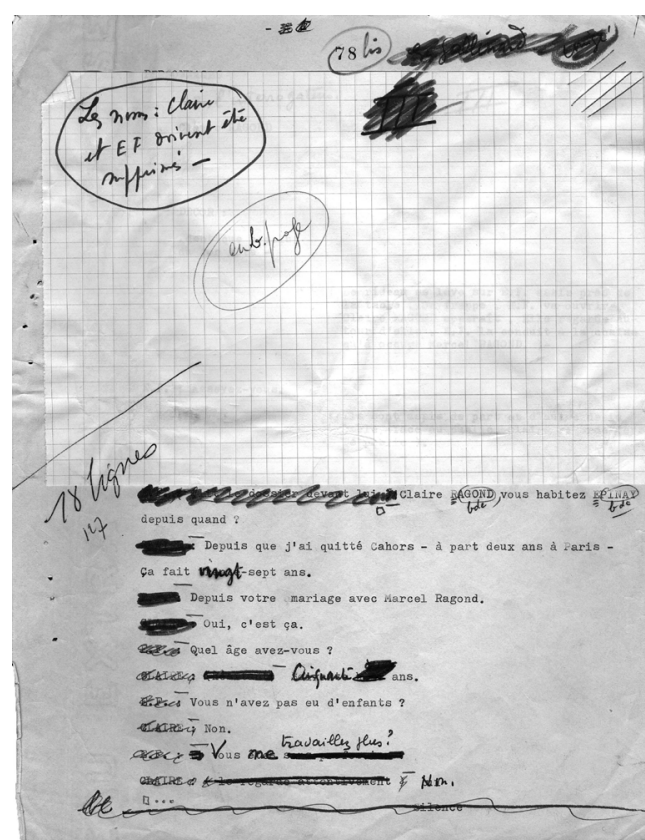

Imagem 4 - Texto datilografado do romance dialogado. Os nomes são riscados a mão (IMEC $7.2 \mathrm{f}^{\circ} 78 \mathrm{bis}$ ).

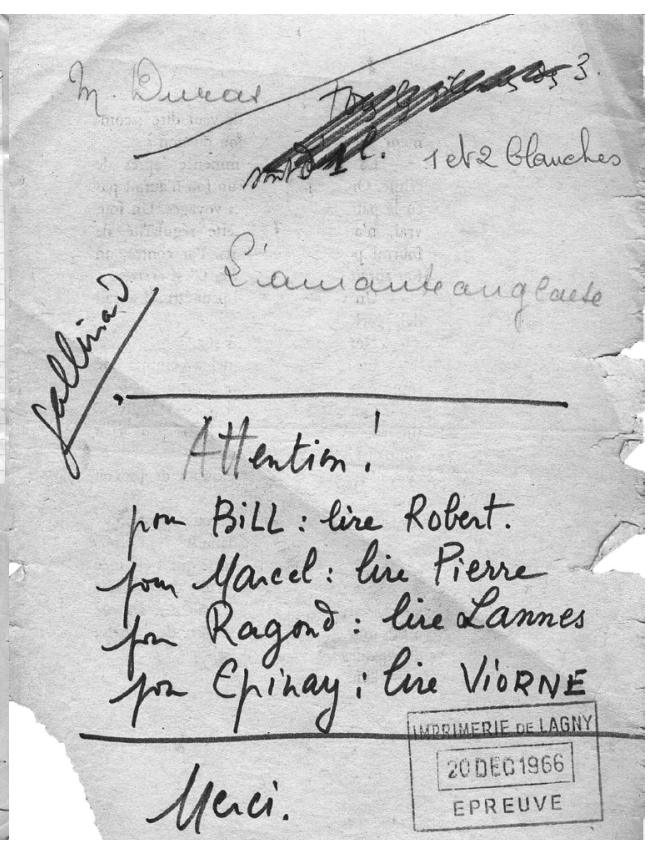

Imagem 5 - Exemplar Gallimard do romance (20 de dezembro de 1966), p. 3. Duras indica as mudanças de nomes a serem efetuadas na totalidade do texto (IMEC 7.3).

Almuth Grésillon; Marie-Madeleine Mervant-Roux - Marguerite Duras/Claude Régy: L'Amante Anglaise, gênese de uma escrita, gestação de um teatro

R. bras. est. pres., Porto Alegre, v. 3, n. 2, p. 515-550, maio/ago. 2013.

Disponível em: <http://www.seer.ufrgs.br/presenca> 


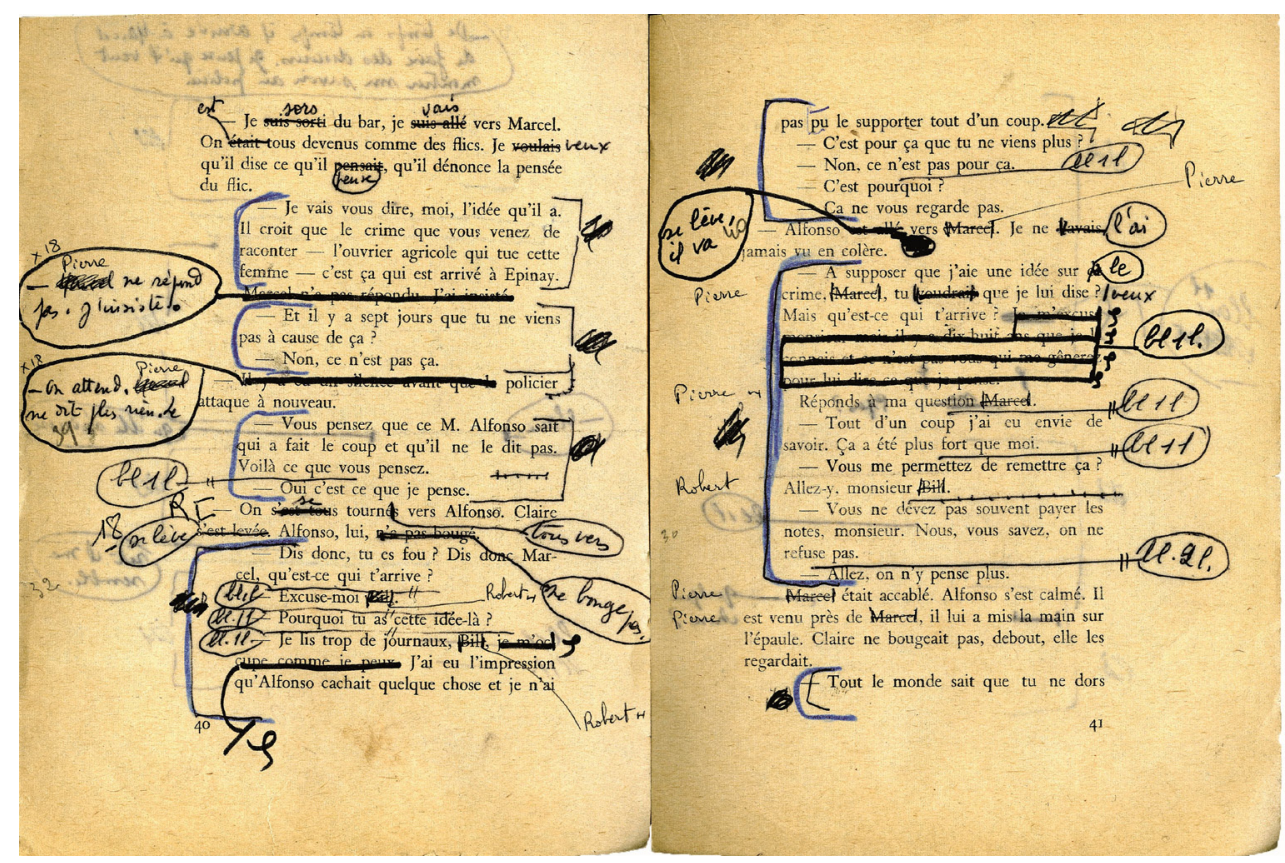

Imagem 6 - L'Amante Anglaise. Exemplar Gallimard do romance (janeiro de 1967), p. 40-41 corrigidas a máo por Duras (IMEC 7.3). Cf. p. 520.

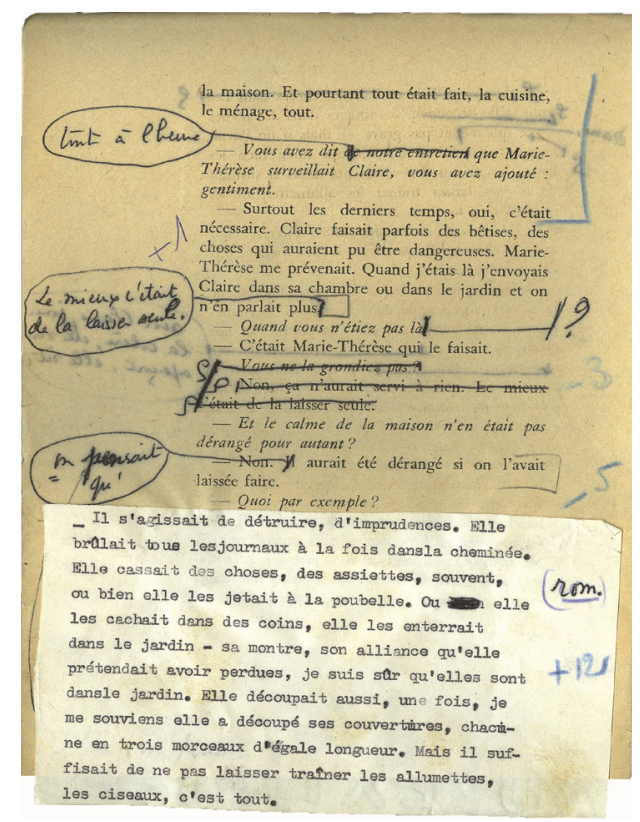

Imagem 7 - L'Amante Anglaise. Exemplar Gallimard do romance (janeiro de 1967), p. 110. Cortes e correçóes à mão, supressão de uma fala coberta por um papel colado sobre o qual Duras datilografou o texto de substituição (IMEC 7.5). Cf. p. 520.

\section{7-1968: do romance L'Amante Anglaise (fevereiro de 1967) ̀̀ criação da peça homônima (dezembro de 1968)}

Na primavera de 1967, quando Marguerite Duras entra novamente em contato com Claude Régy - do qual ela acompanhou a 
evoluçáo e conhece o sucesso - para convidá-lo a ler seu romance, que alguns amigos tinham dito que poderia ser adaptado ao teatro, ele fica impressionado - nessa mesma ordem - "pela escrita e pelos diálogos". Uma primeira leitura foi feita na casa de Michael Lonsdale, que já havia atuado sob a direçáo de Régy; a ideia de um duplo elenco se esboça, um casal jovem (Lonsdale, Loleh Bellon) alternado por um casal mais velho (Madeleine Renaud, Claude Dauphin). O projeto, comercialmente arriscado, é abandonado. Loleh Bellon sai definitivamente de uma gênese na qual ela teve uma participaçáo obscura, mas talvez essencial ${ }^{12}$. Michael Lonsdale, que escolheu o papel do Interrogador, permanece no elenco com o casal de atores conhecidos. A autora e o diretor começam, então, um trabalho a dois: o texto toma rapidamente sua extensão e sua estrutura definitiva.

Marguerite Duras estabelece a primeira forma cênica de L'Amante Anglaise em um caderno de espiral que contém no frontispício a menção Exemplar Duras. O que chama mais a atenção nessa versão cênica, em comparação ao texto do romance, é a condensação. O primeiro capítulo do romance - o interrogatório do patrão do bar da cidade - é suprimido (a pedido expresso de Régy); trata-se, então, de uma peça de dois atos. Alguns acréscimos manuscritos trazem de volta alguns segmentos desaparecidos no momento desse corte importante (Imagem 8): Duras completa a página 2 do caderno acrescentando à mão, na página ao lado $\left(=1 \mathrm{v}^{\circ}\right)$, inserção que é passada a limpo e datilografada na página 2 bis). Em outras páginas, observa-se inúmeros cortes que eliminam detalhes concretos de uma descrição, assim como parágrafos inteiros (como todo o final do primeiro ato, tratando dos papéis escritos de Claire) "cobertos de erros de ortografia". O texto de Duras servia para garantir os primeiros ensaios que, finalmente, só começaram no outono de 1968. Os eventos do mês de maio provocaram provavelmente uma pausa no trabalho durante diversos meses. 


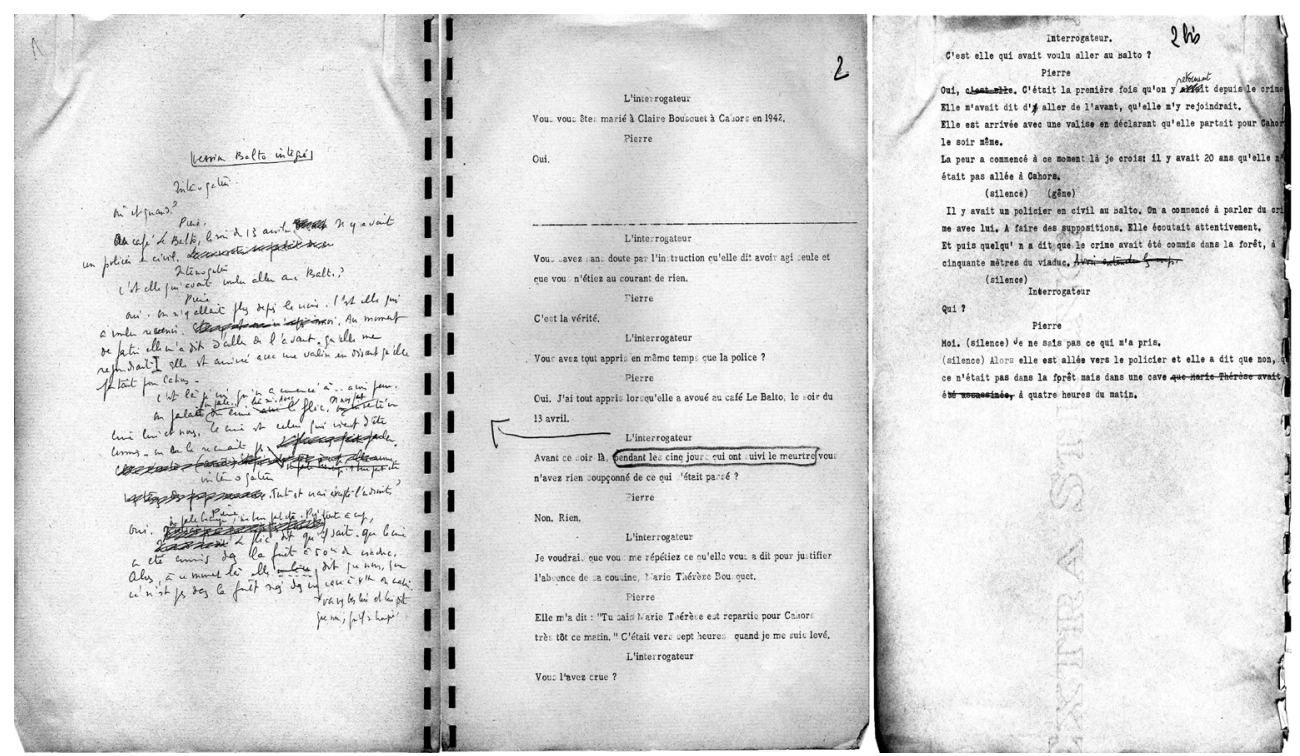

Imagem 8 - Primeira forma cênica de L'Amante Anglaise, caderno em espiral. Folhas $\left[1 v^{\circ}\right], 2$ e 2 bis (IMEC 7.10).

Esse período de maio de 1968, inscrito de maneira visível no "borrão" (abaixo do autógrafo impresso "à Jean Schuster"13, Duras acrescentou à máo "judeu alemáo"), modificou de maneira decisiva as condições de realização do espetáculo: os Renaud-Barrault estavam sem teatro, contatos foram feitos com Georges Wilson, diretor do TNP (Théatre National de Chaillot). No final de outubro, Régy e Jacques Le Marquet, diretor técnico do teatro, visitam a sala Gémier; no início de novembro, o essencial já está decidido. Uma reportagem fotográfica de Roger Pic, realizada em dezembro, mostra uma sala inteiramente reestruturada. Os ensaios começam ali.

É desse período (novembro/dezembro de 1968) que datam os primeiros escritos de Lonsdale no "borrão". Como o livro impresso de L'Amante Anglaise (Gallimard, 1967) se transformou progressivamente em rascunho? $\mathrm{O}$ que significam essas intervençóes manuscritas de três mãos diferentes (as de Duras, de Lonsdale e do assistente)? Esses papéis colados, manuscritos ou datilografados (Imagem 9)? Essas supressóes espetaculares com marcador azul ou preto (ver imagem $1)$ ? Essas páginas que faltam, visivelmente cortadas e suprimidas em relação ao romance (por exemplo, entre as páginas 9 e 22, ou seja, uma boa parte do primeiro capítulo, mas também entre as páginas 57 e 65)? Essas observaçôes escritas a lápis ou com marcador vermelho ou preto? Esses espaços hachurados com cuidado, essas inserçóes manuscritas lançadas por uma máo impulsiva? Na realidade, o as- 
pecto quase pictórico, a riqueza semiótica fascinante do documento se explicam pela densidade temporal dos escritos e pela pluralidade dos escritores. Esses traços escritos são uma espécie de diário datado (ou datável) das transformações operadas sobre o texto desde o outono de 1967. Elas permitem identificar diversos estratos ou camadas cronológicas ${ }^{14}$ que se inscrevem, de alguma maneira, num estado zero, ou seja, no texto do romance.

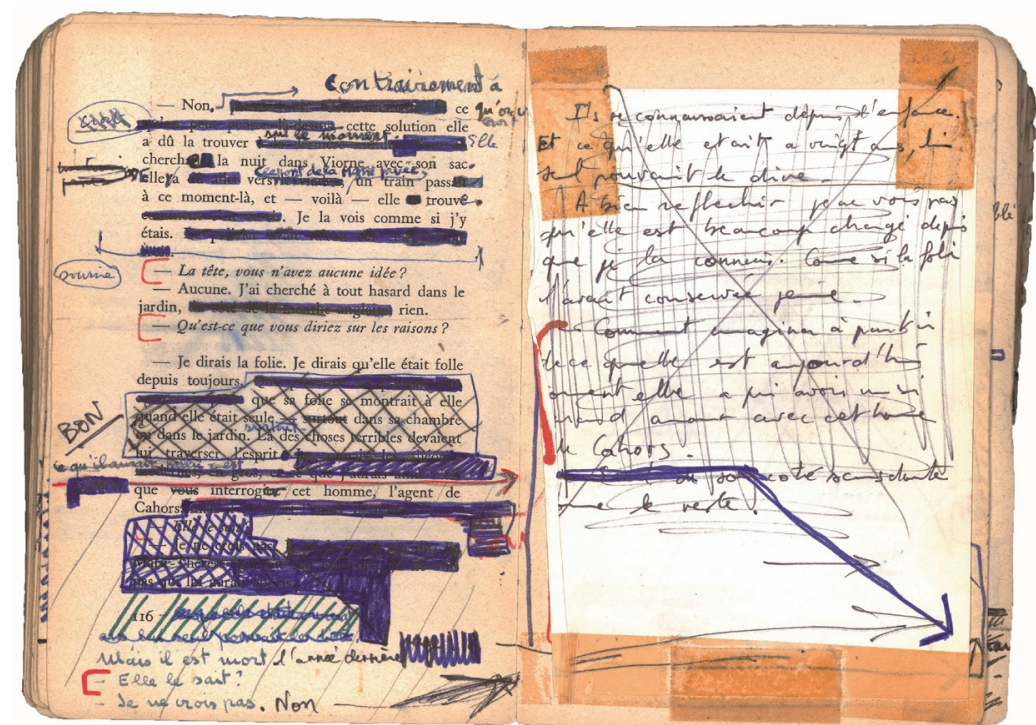

Imagem 9 - L’Amante Anglaise. "Borrão", página 116 do romance: correçôes de diversas mãos, cortes e inserçôes. A página 117 foi inteiramente recoberta por um papel colado com um texto que seria suprimido por sua vez, sem dúvida em um ensaio ulterior. Cf. p. 524.

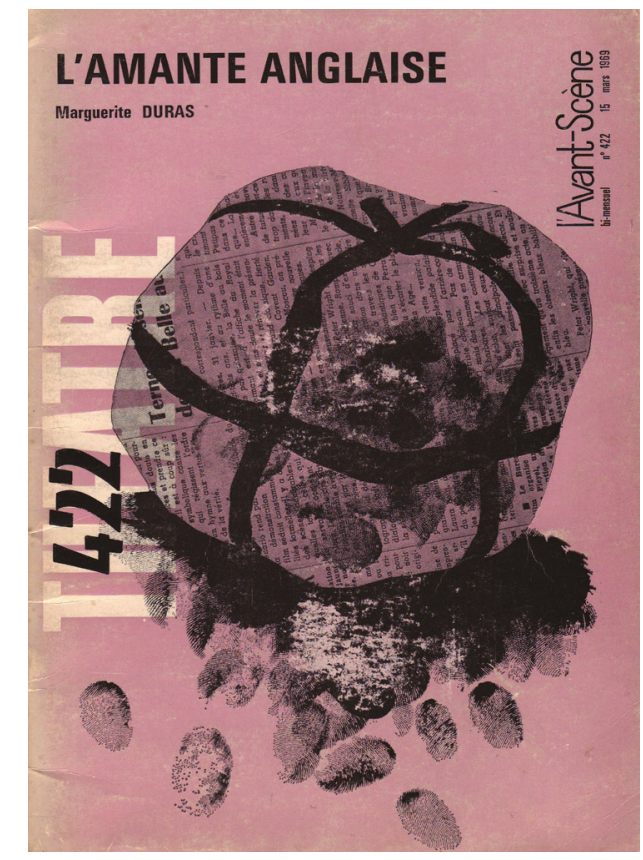

Imagem 10 - L'Amante anglaise. Capa da revista L’Avant-Scène, n. 422, 15 de março de 1969, que comporta a segunda ediçáo do texto teatral. Cf. p. 526. 
Primeiro estrato: Lonsdale assinala de maneira mais plástica as mudanças que Duras já havia efetuado no seu próprio texto.

II

O segundo estrato contém todas as modificaçóes que intervieram durante os ensaios, em novembro e dezembro de 1968; essas são, na sua maioria, da mão de Lonsdale, que, às vezes, também, reescreve, mais cuidadosamente, o que Duras esboçou rapidamente. Tudo leva a pensar que o ator toma notas durante os ensaios e que ele as transcreve, à noite, nesse exemplar do romance para que, no dia seguinte, ele possa dispor de uma versão atualizada. O "borrão" é, entáo, ao mesmo tempo o diário dos ensaios e o texto do ator (Lonsdale assinala com marcador vermelho todas as suas falas).

\section{III}

Um terceiro estrato concerne às modificaçóes que intervieram um pouco antes da estreia (16 de dezembro de 1968); o texto da peça, publicado no dia 13 de dezembro de 1968 na pequena coleção do TNP, traz na última página um quadro com o seguinte comentário: "Essa edição não comporta as modificações feitas no texto durante os últimos ensaios".

IV

Um quarto estrato concerne às mudanças entre essa edição e a da Avant-Scène (n. 422, 15 de março de 1969) (Imagem 10).

$\mathbf{V}$

Um quinto estrato reagrupa todo o resto (as mudanças ocorridas entre março de 1969 e 1989, ano da morte de Duras), inclusive as mudanças que só aparecerão na última edição de 1991.

Esses estratos cronológicos não coincidem termo a termo com as diferentes situaçôes de reescrita. Enquanto o primeiro estrato mostra o trabalho entre a autora e o diretor, os estratos seguintes resultam principalmente dos ensaios e implicam o conjunto dos protagonistas. A partir do quarto estrato, sem dúvida, é preciso incluir a incidência das apresentaçóes e reprises, sem esquecer o eterno desejo de Duras de retomar a posse de seu texto.

Assim, a gênese de L'Amante Anglaise é uma longa história. Iniciada, no sentido estrito, em 1963 (sem voltar ao fato real de 1949, do qual Duras se inspirou, nem à primeira peça Os Viadutos, que ela já havia dedicado a esse mesmo fato real), transitando entre a escrita 
de um romance (publicado em 1967), um roteiro de cinema, um programa de rádio, dando origem a uma peça levada à cena em dezembro de 1968, ela continuará, através de uma sequência de reprises e de turnês do espetáculo, com a mesma direção e, essencialmente, com os mesmos atores ${ }^{15}$, até a morte de Madeleine Renaud em 1989.

\section{Pistas Interpretativas}

\section{A Supressáa como Prova Maior da Passagem do Romance ao Teatro}

Quando se compara os dois textos publicados (na mesma coleção L'Imaginaire da Gallimard), um fato salta aos olhos: enquanto o romance contém 195 páginas, a peça não possui mais do que 109. Essa importante economia não é fruto do acaso, ela resulta de uma estratégia deliberada e corresponde exatamente ao momento de mutação entre romance e teatro. Ela é, talvez, o motor principal dessa mutaçáo. Em todo caso, ela age absolutamente em todos os níveis. Novamente, é o "borráo" que traduz melhor o que Flaubert havia chamado de a arte dos sacrifícios.

Comparemos simplesmente as duas versões de uma resposta de Pierre à questão do interrogador, "Ela não comia?" (Imagem 11): a) romance: "Não, ela não queria. Eu acho que ela comia durante a noite. Ela precisava comer algo". b) teatro: "Não. Eu acho que ela comia durante a noite".

Às dezesseis ${ }^{16}$ palavras da versão romance se opõem nove ${ }^{17} \mathrm{pa}-$ lavras na versão teatro; o "borrão" mostra, nesse lugar, duas rasuras, uma bem forte, feita com um marcador azul e cobrindo tudo; a outra, mais discreta, é feita de um traço fino com caneta azul, datando talvez de uma outra campanha de reescrita.

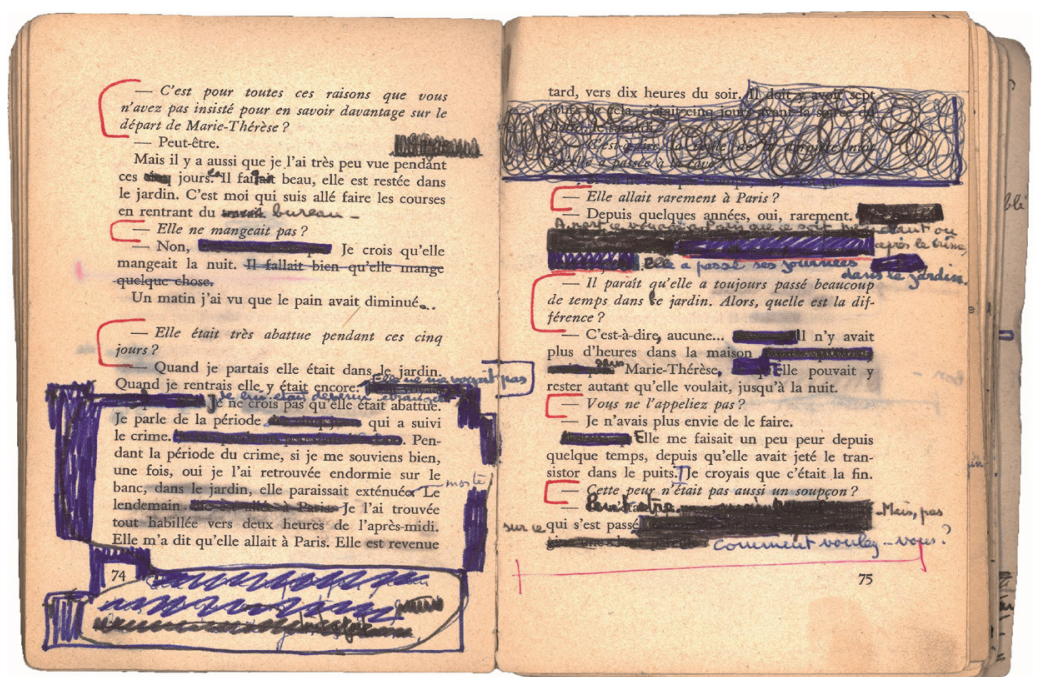

Imagem 11 - L’Amante Anglaise. “Borrão”, páginas 74-75 do romance. Um exemplo de cortes.

Almuth Grésillon; Marie-Madeleine Mervant-Roux - Marguerite Duras/Claude Régy: 


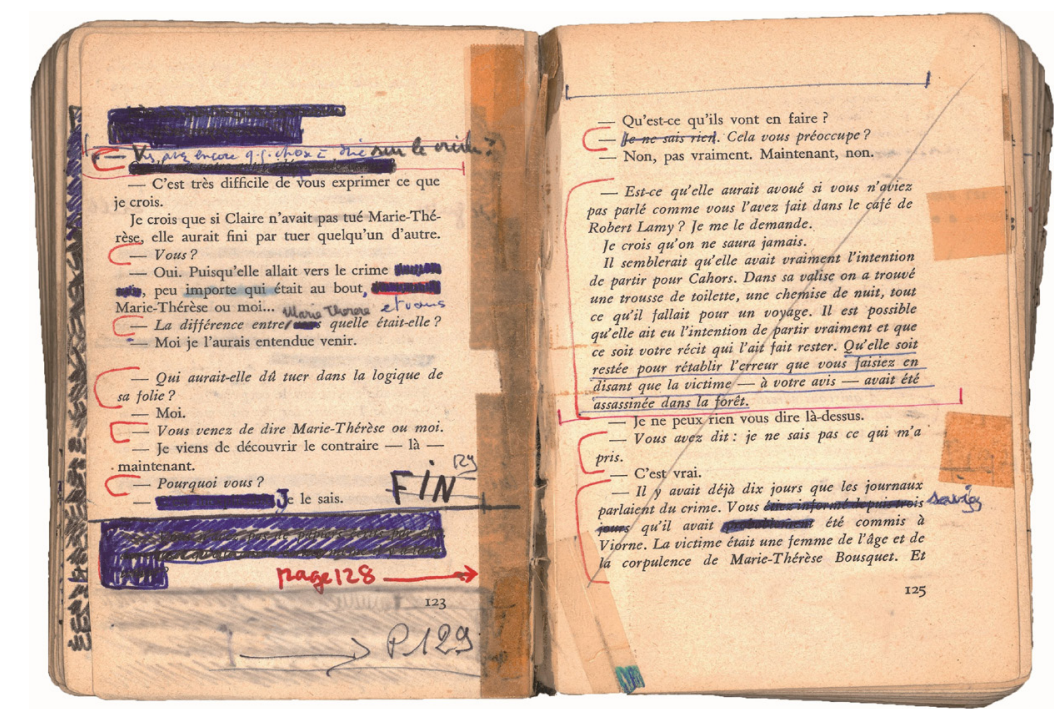

Imagem 12 - “Borrão”, páginas 124-125 [p. 123 e 125 do romance]. Todo o final do primeiro interrogatório é suprimido.

A essas supressóes de palavras ou de (partes de) frases, somam-se reduções e condensações de todos os tipos: supressão de personagens (Robert Lamy, o policial civil, a moça), de episódios (da vida de Alfonso, da vida de Claire; a investigação ferroviária contada por Claire; os dois gravadores; o projeto de um livro sobre o crime; todo o final do primeiro ato - Imagem 12), de detalhes concretos sobre o tempo e o lugar. Mas, a supressão mais importante continua sendo, como já dissemos, o corte da primeira parte, com seu cortejo de fatos pitorescos e sutilidades romanescas (a ideia de uma obra dentro da obra, no livro). O resultado dessa eliminaçáo, buscado por Régy, mas aceito e escrituralmente executado por Maguerite Duras ${ }^{18}$, é uma redução ao mínimo extremo: sobram somente três personagens, um tempo situado em " 13 de abril", um só lugar que - nós o veremos tem tudo de um náo-lugar.

\section{A Gênese Dialética do Espaço}

No teatro, as questóes de produçáo, no sentido econômico do termo, pelo fato de intervirem direta ou indiretamente na escolha do espaço teatral, no elenco, na cenografia, não são exógenas à gênese da obra cênica e podem, até mesmo, ser fundamentais no processo de sua definição. É o caso de L’Amante Anglaise. Certo, a imaginação de Régy já tinha começado a trabalhar a partir da leitura do romance, mais foi apenas ao entrar na sala prevista para o espetáculo, ao observar suas características e suas potencialidades junto com o diretor técnico, 
que ele começou a entrever e a conceber um dispositivo conforme ao que ele começava a sonhar para esse texto novo, uma maneira de não deixar dissolver em um visual decorativo a força sugestiva da escrita.

\section{L'Amante Anglaise (romance): um drama sem lugar}

Esforçando-se para metamorfosear Les Viaducs a fim de fazer uma peça moderna, antes de escolher a forma romanesca, Marguerite Duras já havia trabalhado muito sobre as indicaçóes cênicas, prevendo particularmente efeitos de luz, tentando escapar ao realismo do fato real ocorrido através de transições que sugerissem espaços mentais ou memoriais. No entanto, os elementos tradicionais do cenário foram mantidos: havia uma cortina que subia e descia; o bar era muito simples, mas havia um bar, etc. Uma das grandes diferenças entre o texto romanesco de 1967 e a tentativa dramática anterior seria, entre outras omissóes, aquela de toda informação espacial e de todo acessório, exceto a cadeira e um gravador. "Foi ela que eliminou tudo", dirá Régy. Não é falso, mas, dessa lacuna didascálica, ele soube fazer uma abstração ativa, alterando o modo de escuta do texto e, consequentemente, a posição do espectador, fortemente conduzido ao "imaginamento"19.

\section{A Invenção de um Espaço Plateia-Palco}

Na sua primeira visita à sala Gémier (22 de outubro de 1968), Régy foi guiado por um homem que a conhece intimamente (seu volume, sua capacidade de público, sua cortina-diafragma original). A descoberta do lugar produz efeitos imediatos. Os estudos em papel decalque, efetuados já no dia seguinte por Le Marquet (Imagem 13), mostram a busca por um espaço circular. Os esboços seguintes indicam que a curva da cortina metálica e sua abertura pelo meio retiveram a atenção de Régy. Dia 5 de novembro, um pódio aparece diante da abertura. O eixo principal torna-se frontal e permanecerá assim. Do primeiro projeto subsiste a disposição das cadeiras em volta do pódio em três lados, o que implica a instalaçáo e o recolhimento da totalidade das cadeiras (Imagem 14). A partir do dia 2 de dezembro, Le Marquet fala nas suas notas pessoais de um "espaço plateia-palco" 20 , traduzindo o fato de que claramente é a totalidade do lugar que é repensada: Claude Dauphin e, também, Madeleine Renaud se sentarão, um a um, no minúsculo palco sobrelevado $(2 \mathrm{~m}$ 
x $3 \mathrm{~m}$ x $0,80 \mathrm{~m})$, Michel Lonsdale será instalado praticamente em frente a eles, um plano abaixo, no meio dos espectadores, antes de se aproximar e subir por sua vez no pódio.

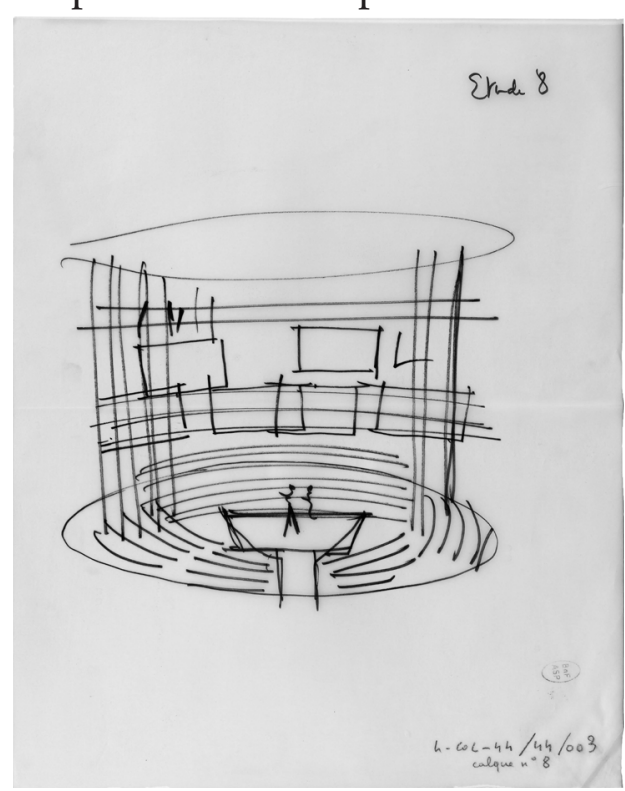

Imagem 13 - Estudo em papel decalque do cenógrafo Jacques Le Marquet, datado de 23 de outubro de 1968 (BnF, Artes do espetáculo, arquivos Le Marquet).

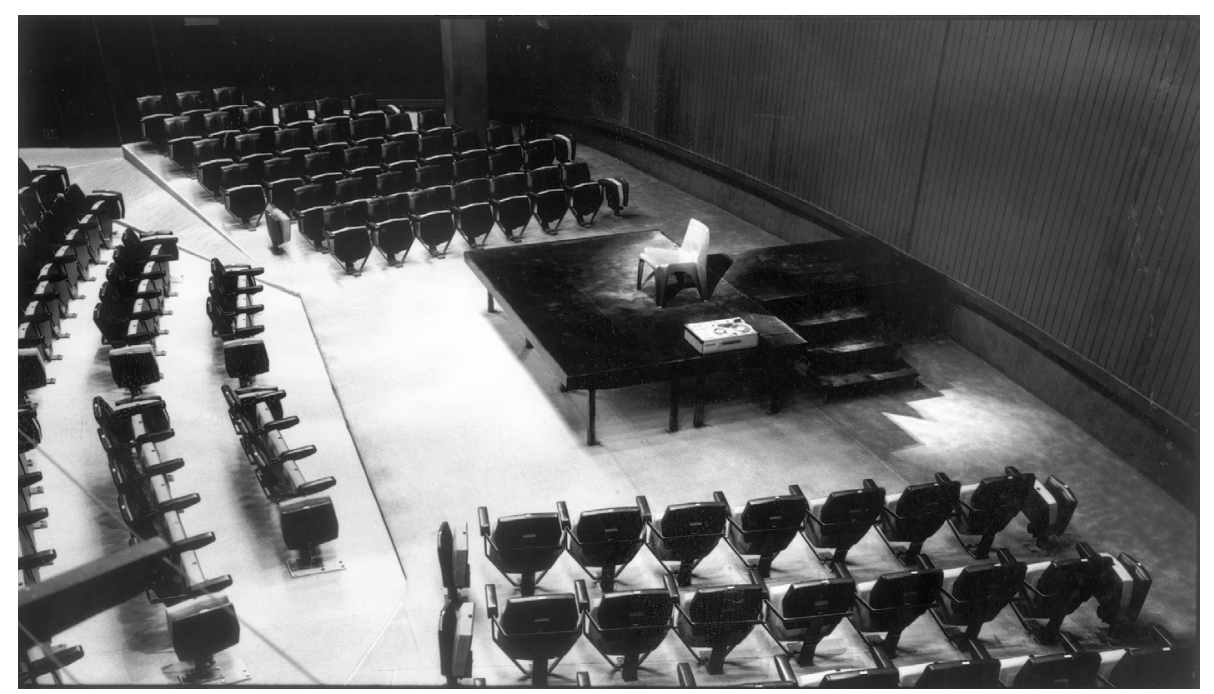

Imagem 14 - A sala Gémier do Théâtre National de Chaillot reorganizada para L'Amante Anglaise. Reportagem fotográfica de Roger Pic, dezembro de 1968 (BnF, Artes do espetáculo, arquivos Chaillot).

O dispositivo final se caracteriza primeiro pelo seu despojamento (ele comporta somente os elementos de base do palco tradicional ocidental: um estrado, uma cortina de fundo aberta, uma poltrona ${ }^{21}$ ) e, em seguida, pela sua escuridáo brilhante: o preto laqueado da cadeira do acusado (uma amostra do revestimento é conservada nos 
arquivos Le Marquet), o preto dos tapetes e da cortina de fundo. Outras notas ulteriores, destinadas aos teatros das turnês, indicam que o preto deve ser liso e sem estampa, sugerindo um "ambiente de prisão glacial", "sobretudo porque a porta central de $4 \mathrm{~m}$ de altura por $1 \mathrm{~m}$ de largura se abrirá de maneira visível para a entrada de Madeleine Renaud"; os arquivos comportam também os desenhos de Yves SaintLaurent para o vestido preto no qual ela aparece. O equipamento original da sala Gémier, que inspirou essa visão surpreendente, deve ser reproduzido, à medida do possível, em todos os outros lugares.

Esse espaço vai influenciar de diferentes maneiras a evoluçáo da escrita: ele materializa a distância entre as figuras; faz do deslocamento do Interrogador um evento; dá ao momento do contato físico com a figura de Claire Lannes uma grande intensidade; cristaliza a abstraçáo e sua carga emocional, incita o grupo de criadores a ir ainda mais longe no despojamento, a inventar um jogo de vozes.

Assim como a dupla autora e diretor, hoje inscrita na história oficial do teatro, forma-se, durante essa gênese, outro duo decisivo, sem o qual o primeiro talvez náo tivesse se formado, o de Régy e Le Marquet. Eles farão treze trabalhos em conjunto.

\section{Personagens - Atores - Vozes}

Desde os mais velhos rascunhos, observamos uma hesitação nos nomes dos personagens; ora eles aparecem com todas as letras, ora somente com as iniciais (não necessariamente identificáveis: é o caso de "E. F."), eles podem também ser suprimidos ou modificados: "Amelie Rabilloud", do fato real de 1949, torna-se "Claire Ragond" nos Viaducs, se transformando em "Claire Lannes, nascida com o nome de Bousquet", para se chamar finalmente "Claire Amelie Lannes" no texto de 1991. "Amelie" refere-se discretamente ao fato real inicial. Existe, também, um depoimento estranho no qual Duras confunde um nome de personagem com o nome do ator correspondente. Com efeito, no frontispício de um "roteiro 1982 com 3 personagens", ela escreve: "Robert Lamy/Claire Lannes/Pierre Dux", este último interpretava o personagem de Pierre Lannes.

Essa hesitação conduz progressivamente a uma desencarnaçãoabstração dos personagens, que se manifesta com maior ênfase por intermédio do Interrogador, ininterruptamente interpretado por Michael Lonsdale. Desde o início, esse papel é somente uma função, 
desprovida de nome próprio. Não é um interrogador, mas uma espécie de quintessência de todos os interrogadores, como se o genérico excluísse imediatamente a existência de um corpo e de um nome. Lembramos que o personagem permanece durante muito tempo invisível para o público e só sobe no pódio no final da peça. Na edição de 1991, Duras indica em uma nota que o interrogador "não tem um lugar fixo na encenação. Ele faz o que quer. Ele caminha. Refaz seu caminho, para, se cala, se encosta nas portas, nas paredes, às vezes, ele se cala durante longos segundos. [...] Ele é desesperado por ela, para ela - ele possui a lentidáo do desespero" (Duras, 1991, p. 16-17).

Aliás, é ele que conduz a investigação, a conduz tomado partido e sem dissimulá-lo. Desde o romance de 1967, ele diz a Robert Lamy (o patrão do bar): "Eu quero saber quem é essa mulher, Claire Lannes, e porque ela diz ter cometido esse crime. Ela não dá nenhum motivo para ter cometido esse crime. Entáo, eu procuro por ela" (1967, p. 62). Esse autorretrato faz parte da primeira parte do romance, suprimida na passagem à peça. Duras deseja reintegrá-lo, dessa vez como resposta a Pierre Lannes ${ }^{22}$. A missáo do interrogador se limita a desvendar o segredo de Claire, o personagem é somente um mediador, um porta-voz, uma voz para se aproximar de Claire; a voz de Duras, poder-se-ia dizer, quando se lê esse pequeno comentário que ela escreveu no verão de 1989:

O interrogador é alguém que conhecia a história do crime cometido por Claire Lannes, mas que ignorava tudo sobre a existência de Claire Lannes. É aí, diante de nós, que o interrogador descobre a pessoa de Claire Lannes e sua voz, a força do querer desse corpo assassino [...]. O interrogador, aqui, não tem identidade definida. Ele está largado, ali, sem papel algum, e parece que era isso que se queria dele, que ele se perdesse ali, e junto com ele um certo teatro, o próprio teatro [...]. Se existe aqui um personagem que poderia ser identificado com o autor, não é ele, é ela, Claire. Procurar a identidade do interrogador é um falso problema. Ele náo possui nada que se pareça com isso. $\mathrm{O}$ interrogador também náo tem um lugar que lhe seja designado. Ele não tem onde 'se meter', nem na plateia, nem no palco, nem no espaço fechado da cena, nem no da plateia (Arquivos privados de Jean Mascolo).

Em suma, Michael Lonsdale, que é um grande ator, em vez de interpretar um personagem, emprestou sua voz a Marguerite Duras - assim como ele lhe emprestou sua pluma quando se tratava de conservar no seu "borrão magnífico" os vestígios das modificaçôes que intervieram durante os ensaios. 


\section{Um Sutil Trabalho sobre a Lingua}

O lento processo de redação e de transformação ao final do qual nasce uma obra teatral chamada L'Amante Anglaise é, também, um intenso trabalho sobre a língua. Náo se trata de criar efeitos de real (como contar em cena a história de um crime?), mas, ao contrário, de desconstruir a lógica da linguagem comum, de desfamiliarizar o ouvido, introduzindo elementos de ruptura, de surpresa, de estranheza. Gostaríamos de mostrar aqui o trabalho escritural da maneira como ele pode ser observado diretamente nos documentos de gênese. Limitemo-nos a um só exemplo: o nascimento de homofonias em torno do título da peça.

O nome L'Amante Anglaise aparece desde cedo, nos rascunhos do romance, visivelmente acrescentado à máo numa página datilografada. Seu significado permanecera obstinadamente opaco, mas o nome designa a mulher assassina. Da mesma fase data uma fala do marido à "E. F.", que o interroga sobre sua esposa:

[...] às vezes ela falava de um jeito estranho, um pouco como se recitasse frases escritas que ela teria lido em alguns livros modernos, mas claro que não. Eu me lembro de duas ou três coisas sobre as flores do jardim. Ela dizia: "A menta inglesa é magra, preta, tem flores que não lhe olham" (IMEC, arquivos Duras, cota 7.1, f f 51, grifado por nós).

Há aí uma simples homofonia que o leitor estabelece entre "a amante inglesa" e "a menta inglesa" 23 , mas as duas apariçóes se encontram longe uma da outra.

Em outros manuscritos, mais antigos, a homofonia aparece in praesentia, em correçóes manuscritas significativas. Os acréscimos manuscritos aparecem entre colchetes, os fragmentos riscados à máo aparecem barrados:

- Há dois ou três anos eu encontrei dois ou três rascunhos de uma carta manuscrita que ela tinha escrito para um jornal de Versailles. Era quase ilegível, coberta de erros de ortografia. Eu as queimei.

- Do que se tratava?

- Eu quase nem li. Creio que ela pedia conselhos sobre o jardim, sim, sobre a menta <inglesa $>$, ela perguntava como conservá-la dentro de casa, no inverno. A menta, ela escrevia isso como uma amante, um amante, uma amante. E "inglesa", <"en glaise"> ${ }^{24}$, como "na terra", "na areia". (um tempo) Pode-se erer, eu sei, que sejam erros que querem dizer algo, mas eu não ereio. (IMEC, arquivos Duras, cota 7.8, f $^{\circ} 21$; grifado por nós). 
Desses "erros de ortografia" nasceu, então, uma dupla homofonia entre "a amante inglesa" e "a menta en glaise" que aparecerá assim no texto impresso do romance (1967, p. 124). Ora, no seu texto pessoal (7.10, fo 53$)$, Duras cortou "en glaise", eliminando assim a homofonia com "inglesa". O mesmo fenômeno pode ser constatado no "borráo", no qual Lonsdale materializa esse corte de Duras com um espesso traço de marcador azul (ver imagem 1). O mesmo movimento de remoção aparece um pouco mais acima no texto do romance, no qual o marido, interrogado sobre a cabeça da vítima, responde: "Eu procurei por acaso, no jardim, do lado da menta inglesa" (p. 116, grifado por nós); no "borráo", "do lado da menta inglesa" é suprimido e não aparecerá mais nas diversas ediçôes da peça.

Durante o interrogatório da esposa, aparece de novo a questáo do jardim onde cresce a menta:

Há um banco de cimento e pés de amante inglesa, é a minha planta preferida. É uma planta que se come, que cresce nas ilhas onde ficam as ovelhas. Eu pensei: a amante inglesa é o contrário da carne com molho. Devo dizer-lhes que, às vezes, eu me senti muito inteligente sentada nesse banco de cimento (Duras, 1967, p. 150-151. Grifado por nós).

Dessa vez, a homofonia inicial a mentala amante se prolonga até os pés de mentalpés da amante. Por outro lado, o jogo com a língua traz palavras que rimam: menta, amante, planta ${ }^{25}$, e, também, com rima parcial: banco e cimento ${ }^{26}$. Sem esquecer que a segunda sílaba de cimento $^{27}$ evoca diretamente a questáo colocada inúmeras vezes no texto: "Quem mente?" 28 . Há um último caso, estranho, ligado ao banco de cimento: ausente no romance, inserida à mão no texto pessoal (7.10, f49), uma frase da assassina intervém sem transição, brutal, sem contexto, quando ela dá-se conta de que não há mais nada a dizer: "Às vezes minha boca era como o cimento do banco". $\mathrm{Na}$ edição de 1991, a imagem perde uma parte da sua brutalidade, sendo inserida num contexto explícito: "Se eu não tivesse cometido esse crime, eu ainda estaria ali, no meu jardim, calada. Às vezes, minha boca era como o cimento do banco" (Duras, Le Théâtre de l'Amante Anglaise, 1991, p. 93).

Tudo se passa como se Duras se deixasse levar, num primeiro momento, livremente pela criação verbal, contendo-se em seguida para náo poetizar demais a língua da cena.

Quanto ao título L'Amante Anglaise, nenhum documento de gênese fornece qualquer explicação. Poderíamos imaginar que Duras 
tenha lido a peça de Alexandre Dumas Filho, Um Caso de Ruptura, na edição ilustrada por Eugène Courboin (Paris, Ancienne Maison Quartier, 1892), comportando um desenho sugestivo intitulado L'Amante Anglaise (p. 44)? No que diz respeito "à menta inglesa", trata-se simplesmente de um sinônimo de "hortelá-pimenta".

\section{A Elaboraçáo do Inacabamento}

No final do interrogatório de Claire Lannes, náo se sabe onde está a cabeça da vítima, desconhece-se a razão do crime. No plano dramatúrgico, L’Amante Anglaise termina, então, com um duplo enigma. O estudo das oito versôes sucessivas do final do texto (de 1966 a 1991) mostra que, para a autora e o diretor, o essencial não está ali.

\section{I}

Manuscritos de preparação do romance (7.2, p. 118). A última resposta de Claire termina com uma dupla afirmaçáo: a expressáo repetida de um desejo apocalíptico e a denegação do desejo de matar sua prima: "Eu queria lhe quebrar a cara, colocar fogo na casa [...] e que ele, de pijama, fugisse nas ruas de Epinay e eu correndo atrás dele, e que tudo terminasse [...] em destroços e eu no meio, com a bandeira da loucura na mão, chamando as pessoas de Epinay para ver como eu estava louca, mas matá-la, não”.

\section{II}

Primeiras versóes do romance (7.3, 20/12/1966, p. 184). O essencial do roteiro imaginado é mantido, Epinay tornando-se Viorne. A palavra "destroços" 29 é substituída por "agitação"30 e o final é nitidamente encurtado: Duras suprime a imagem da bandeira e a alusão à loucura.

\section{III}

Segundas versöes do romance (7.4, 9/1/1967, p. 194). Desaparecimento dos elementos restantes: o incêndio, a perseguição. Aparição da imagem da casa e das três portas do térreo (sala de jantar, corredor, quarto da prima): "[...] sempre abertas, alinhadas, e todas do mesmo lado, elas pesavam sobre a parede do mesmo lado, podia-se pensar que a casa se inclinava para esse lado, e que ela tinha rolado para o fundo, levada pela inclinação, ao lado das portas, era preciso se segurar nos corrimóes". A frase "Eu, no se lugar, ouviria. Me ouça", 
que precedia a narrativa da fuga na cidade, é deslocada. Ela constitui doravante o final do texto.

\section{IV}

Texto de Marguerite Duras 1967-1968 (7.10, p. II-49). Os três breves parágrafos que precedem a narrativa da fuga na cidade são suprimidos também, o comentário de Claire: "Isso sempre acontece do mesmo jeito, que se tenha cometido um crime ou não" vem imediatamente seguido da imagem da casa. A frase "Às vezes minha boca era como o cimento do banco", escrita à mão na margem da folha, vem se inserir entre as duas. $\mathrm{Na}$ evocação da inclinação imaginária, o pronome "ela" ("ela tinha rolado para o fundo") torna-se "a morta". O fim do texto permanece inalterado.

\section{V}

"Borráo" (p. 194-195). As modificaçóes do texto são confirmadas, com exceção de um detalhe: a questão: "eu lhe disse?", associada no romance a uma conversa banal, suprimida junto com ele, é restaurada e colocada depois da imagem da boca-cimento (Imagem 15).

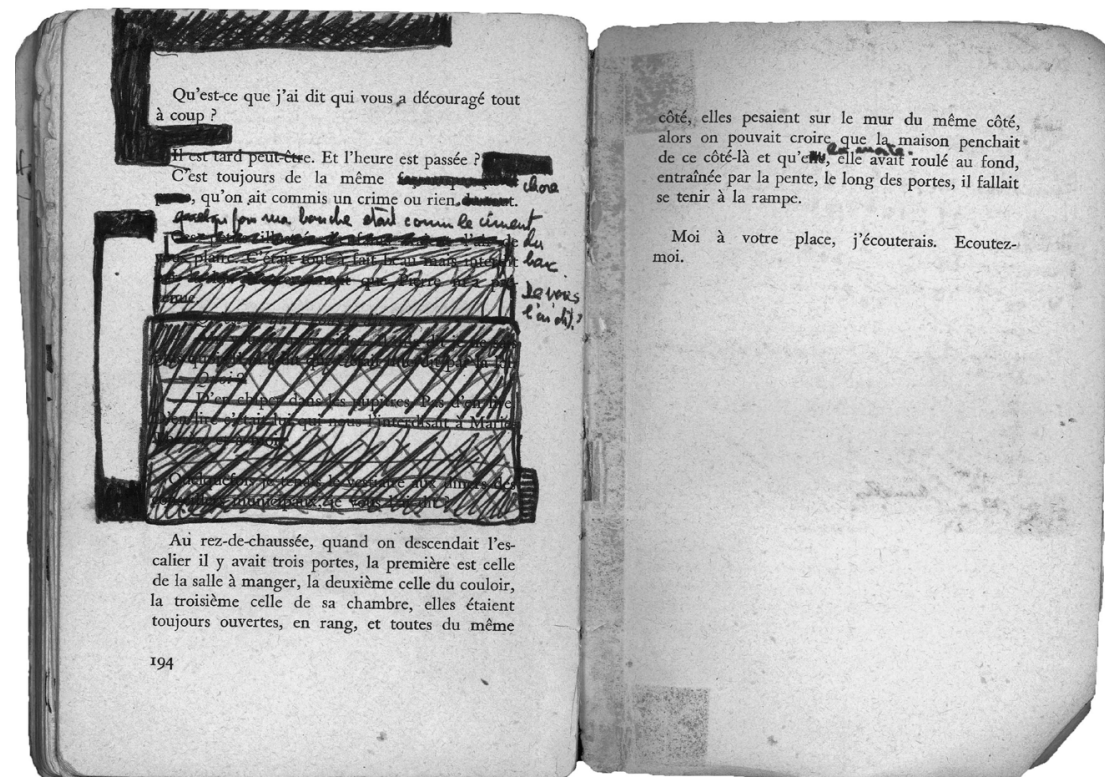

Imagem 15 - "Rascunho", páginas 194-195. Último remanejamento manuscrito: “às vezes minha boca era como o cimento do banco. Eu lhe disse?".

Dois princípios sucessivos parecem ter presidido essa transformação: primeiro, a vontade de atenuar o "efeito de fim", o "teatral", no sentido espetacular e pejorativo do termo (a casa em fogo, a "agitaçáo", a bandeira), a rejeição de uma encenação onírica, exterior, da loucura e, também, incitada pela perspectiva concreta da cena, a busca de 
uma escrita suscetível de traduzir a inventividade expressiva de Claire: colagem surpreendente de imagens estranhas dos dois lugares-chave de L'Amante, o banco do jardim e a casa, prolongação e renovação dos jogos homofônicos que pela primeira vez são diretamente ligados à palavra ("minha boca"/"cimento"/"se [ela] mente"), jogo discreto de assonâncias ("quarto", "inclina", "inclinaçáo", "corrimão") ${ }^{31}$, como se o verdadeiro enigma não fosse tanto o crime, mas essa expressão poderosa em breve novamente sem escuta ${ }^{32}$. É preciso evocar aqui o caráter permanente da variação na própria obra de Duras. A variação é um componente estrutural da arte viva que é o teatro, no entanto, é raro que os autores acompanhem esse movimento, mais raro ainda que eles o prolonguem para além da criação cênica. Em 1989, durante os ensaios do que deveria ser a última reprise do espetáculo, a autora, preparando sozinha a edição Gallimard, efetua um último acréscimo no final de seu texto. Três palavras: "Eu lhe imploro". Claude Régy comentou esse gesto em 2005. Primeiro num tom de brincadeira: "Marguerite conseguiu finalmente ter a última palavra [...]", antes de sugerir outra hipótese: ela teria se conformado na verdade ao inacabamento do teatro. "Não se deixar fixar pela forma. E ela atingiu seu intento, pois não existe nenhuma versão da qual se possa dizer: essa é a correta" 33 .

\section{Conclusão}

A beleza do "borráo" e o aspecto bem sucedido dessa gênese colaborativa não podem esconder a função geral desse estudo, concebido e conduzido como um exercício de interdisciplinaridade entre a crítica genética e os estudos teatrais. O primeiro resultado do cruzamento das abordagens diz respeito à velha questão do autor da obra teatral. Esse estudo mostra a necessidade de um modelo mais afinado do que os dois modelos existentes. O primeiro, construído sobre o duo autor/diretor ignora as intervençóes dos atores, do cenógrafo, etc., que se mostraram decisivas no processo de criação; ele deixa também de lado o peso da produção econômica e técnica que pode ser determinante na gênese teatral, como mostra o exemplo da sala Gémier. O segundo modelo, baseado na ideia do coletivo, traduz mal a sutileza de práticas colaborativas nas quais a responsabilidade de cada um é redefinida pelo conjunto da encenaçáo. Enquanto eles ensaiavam a sequência final de L'Amante, Michael Lonsdale, aproximando-se de 
Madeleine Renaud, colocou espontaneamente as máos nos seus ombros e, depois, na cabeça da atriz (Imagem 17), gesto que Claude Régy decidiu conservar. $\mathrm{O}$ ator anota esse detalhe didascálico na margem da página 183 do "borrão" (Imagem 16). No prefácio da edição de 1991, que não comporta essa indicação, Marguerite Duras descreve esse momento, ela o imagina e o reinventa: "ele [...] colocava as mãos nos seus cabelos e permanecia ali até o fim" (Duras, 1991, p. 17).

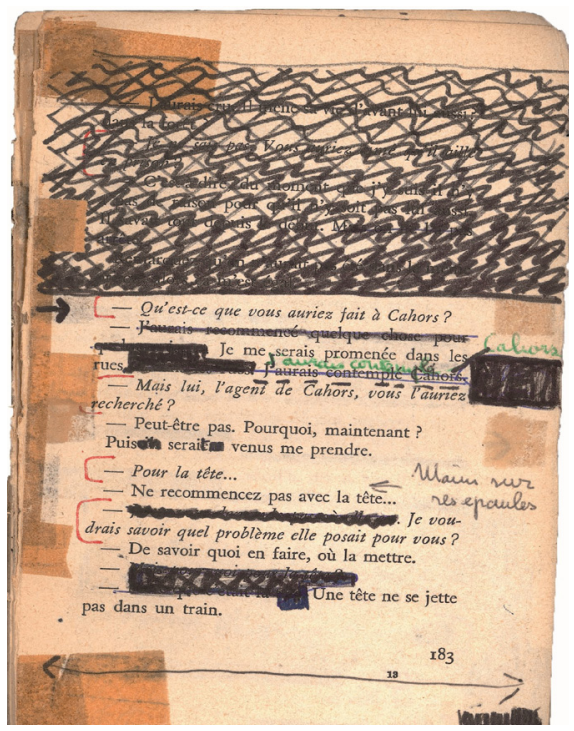

Imagem 16 - L'Amante Anglaise. "Rascunho", p. 183. O acréscimo manuscrito da rubrica:

"Mãos nos seus ombros" corresponde ao gesto do ator.

Convém, assim, terminar com o dilema surgido nos primeiros ensaios de gênese teatral: deve-se privilegiar o texto dramático ou partir da encenação? Esse dilema parece ter por origem a divisão histórica das disciplinas acadêmicas: estudos literários versus artes do espetáculo, divisão que a exploração genética torna confusa. Mesmo nos casos nos quais existe, como em L'Amante Anglaise, um texto inicial e uma encenação, é difícil dissociar os campos de estudo: em que campo colocar o "borrão"? Certo, ele constitui um estado do que chamamos de texto, porém interno ao trabalho cênico, no qual as palavras são pronunciadas por alguém que as usa como ator e essas náo são mais exatamente aquelas que o autor tinha ouvido. Inversamente, os escritos do cenógrafo, considerados normalmente como documentos da encenação, tem o mesmo valor que as rubricas, classificadas, elas, no campo do texto. Para colocar em evidência a complexidade das situaçóes teatrais, seria preciso dissociar cuidadosamente as diferentes funçóes dos materiais textuais no interior de 
uma mesma gênese e elaborar um esquema teórico aberto a todos os casos possíveis - da criação cênica efetuada sem nenhum texto preexistente até o texto dramático nunca montado.

A última lição deste estudo é uma questão, ligada a uma especificidade absoluta do fenômeno teatral. Se o espetáculo de 1968 adquiriu a força que se conhece, se as escolhas iniciais dos artistas foram mantidas, reforçadas, se essa L'Amante Anglaise viveu décadas de metamorfoses, é porque o público respondeu com uma escuta ativa e intensa a uma proposta cênica arriscada. No teatro, o espectador intervém concretamente no ritmo, na intensidade e finalmente na vida real da obra. Onde encerrar, entáo, a gênese do espetáculo?

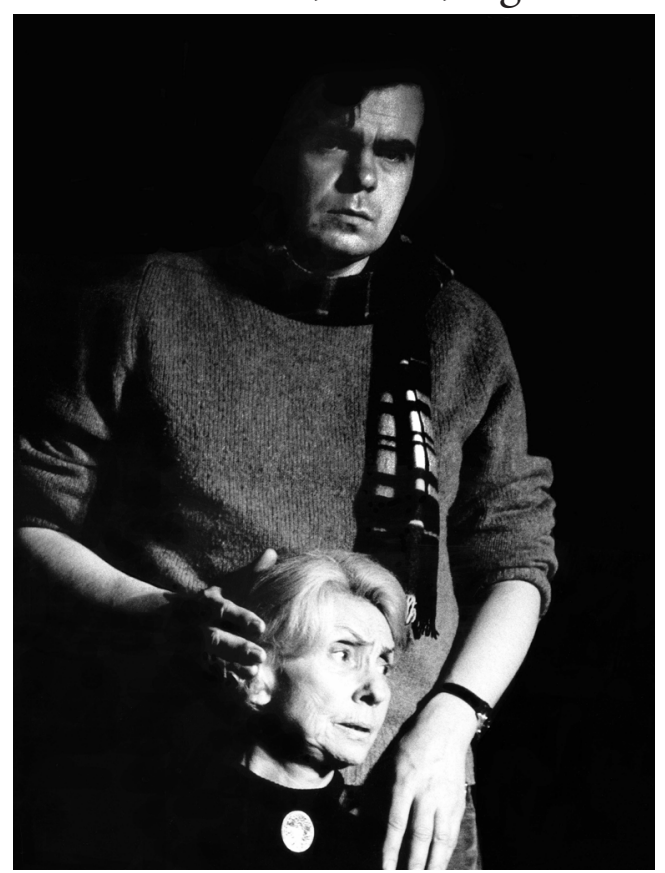

Imagem 17 - Michael Lonsdale e Madeleine Renaud, foto de ensaio (col. pessoal de M. Lonsdale, DR). 


\section{Os Arquivos Sonoros de L'Amante Anglaise [TNP, 1969, ence- nação do espetáculo] ${ }^{34}$}

"Infelizmente, escrevíamos no estudo publicado em outubro de 2010, alguns documentos não foram encontrados: o texto do diretor, a gravação sonora do espetáculo efetuada provavelmente no $\mathrm{TNP}^{35} \mathrm{e}$, o que é mais surpreendente, quase todos os documentos radiofônicos".

No que se refere aos documentos radiofônicos, tinha-se encontrado vestígios de diversos projetos de criação ou de transmissão de L'Amante Anglaise no rádio, mas nenhum parece ter sido levado a cabo. Quanto à gravaçáo sonora do espetáculo no TNP, foi Michael Lonsdale, o Interrogador nas diversas versóes sucessivas do espetáculo, que nos falou de sua existência. Ele tinha certeza de que o espetáculo havia sido gravado na sala Gémier - logo, entre o dia 16 de dezembro 1968, data da estreia, e o dia 30 de dezembro de 1969, última apresentação nesse teatro. Ele preferia uma gravação cinematográfica -, mas essa nunca foi realizada.

Dia 29 de novembro de 2010, eu recebi este e-mail de um doutorando, Guillaume Trivulce:

Eu lhe escrevo após ter começado a leitura de seu livro Genèses théatrales. Eu li que você lamentava o fato de não ter encontrado o registro sonoro do espetáculo de Régy. Eu o escutei sexta-feira passada em duas gravaçóes diferentes. Essas gravações estão por enquanto datadas de 1968 e vêm dos arquivos Georges Wilson. Achei que isso poderia lhe interessar.

Esse estudante havia sido escolhido como pesquisador associado pela $\mathrm{BnF}$ para inventariar os arquivos audiovisuais do TNP. Joël Huthwohl, diretor do departamento de Artes do Espetáculo da $\mathrm{BnF}$, e eu mesma, começamos entâo uma nova pesquisa para identificar o conjunto dos documentos de áudio relativos ao espetáculo, um conjunto de cinco bobinas de fitas, recentemente digitalizadas. Após duas escutas integrais da nossa parte, a primeira efetuada em companhia de Michael Lonsdale, a segunda em companhia de Claude Régy, e depois da consulta da cronologia precisa, feita por Almuth Grésillon e eu mesma em 2010 das diversas apresentaçóes da primeira versão cênica (1968-1969), na qual dois atores se alternam no papel de Pierre Lannes, as duas gravaçóes diferentes puderam ser identificadas como sendo as das apresentaçóes do dia 22 de fevereiro de 1969 (com Claude Dauphin) e do dia 21 de dezembro do mesmo ano (com Jean Servais). Além dessas duas gravaçôes, que permitem ouvir o espetáculo em duas versóes diferentes, com dez meses de 
intervalo entre elas, os documentos de áudio continham, também, os ensaios do fragmento transmitido pelo megafone instalado no pequeno palco, fragmento retrabalhado com Jean Servais na sua entrada no espetáculo, pois ouve-se a voz de Pierre Lannes. Enfim, esse dossiê de áudio continha a trilha sonora, ou seja, os elementos pré-gravados: alguns minutos de A Arte da Fuga (J. S. Bach), que abria o espetáculo, e o anúncio inicial, gravado por François Périer.

Essas duas sessóes nos mostraram como cada escuta pode ser diferente e preciosa pelas informaçôes que se pode tirar. Michael Lonsdale veio ouvir as gravaçóes no escritório de Joël Hutwohl, na BnF, no dia 17 de julho de 2012. Na mais antiga, esperávamos ouvir Claude Dauphin. Já nas primeiras falas, Michael Lonsdale nos diz que se trata da voz de Jean Servais. A numeração das bobinas estava invertida. Sem a ajuda de Michael Lonsdale, teríamos observado essa inversão? Lonsdale surpreende-se pelo frasear rápido e pela articulação relaxada de Servais: "ele enrola". Depois ele acha que Dauphin está mais preciso, mais popular. Ele pensa que o microfone estava próximo demais e observa as tosses recorrentes dos espectadores. A entrada em cena de Madeleine Renaud produz um efeito imediato. A sessão com Claude Régy acontece na casa dele. Nós escutamos a versão de Claude Dauphin, que ele considera muito naturalista. Para Régy, a voz de Lonsdale está deformada, o que confirma a observação desse último sobre a proximidade do microfone. A entrada em cena de Madeleine Renaud produz de novo um grande efeito. Régy fala do instinto dela, maior que a sua compreensão do texto. Ele diz, também, que ela tinha dificuldade com os silêncios. Ela "vai em frente" sem marcá-los. É Lonsdale que tem que esperar e frear de certa maneira.

\section{Os Arquivos Sonoros: riquezas e dificuldades específicas}

Antes de uma enunciação, necessariamente rápida no contexto deste anexo, do que o conjunto de fitas magnéticas encontradas poderia trazer ao estudo de gênese de L'Amante Anglaise, convém lembrar a dificuldade de exploração dos arquivos sonoros em geral e das gravaçôes de apresentaçóes em público em particular ${ }^{36}$.

A primeira questão, de ordem geral e importantíssima, é a da audibilidade, colocada em termos claros por Jonathan Sterne no livro The Audible Past:

Podemos ouvir vestígios do passado histórico em gravaçóes, mas náo podemos considerar que sabemos como era ouvir em um determinado tempo ou lugar no passado. $\mathrm{Na}$ era 
da reprodução tecnológica, podemos às vezes experimentar um passado audível, mas não podemos fazer nada mais do que pressupor a existência de um passado auditivo ${ }^{37}$.

Mesmo se a temporada de 1968-1969 parece próxima, trata-se na realidade de um mundo sonoro e auditivo desaparecido, uma paisagem vocal (teatral, cinematográfica, radiofônica) desaparecida, um mundo tecnológico (a peça evoca um transistor, uma televisáo, um gravador), também desaparecido.

Ora, o documento sonoro dá ao auditor a impressão de uma presença no presente. "O sonoro vive no presente", escreve Daniel Deshays $^{38}$. Ao contrário de uma fotografia, que se pode optar por observar durante mais ou menos tempo, a gravação sonora surge e desenvolve sua própria temporalidade, que nos é imposta. É difícil então manter uma distância em relação ao nosso próprio ouvido espontâneo, não transmitir nossas reações, nossas emoções aos primeiros ouvintes do documento ou do som fixado no documento. Essa tentação é evocada pelo historiógrafo Alain Corbin:

A renúncia da humildade que consiste em se colocar na escuta dos homens do passado a fim de detectar e náo de decretar as paixóes que os animavam vai ao encontro da desaparição dessa leitura dos sons que constituíam uma paisagem sonora ${ }^{39}$.

A gravação de um espetáculo traz ainda outros problemas.

$\mathrm{O}$ primeiro deles é de ordem técnica. Frequentemente, a gravação, como foi o caso da criação de L'Amante Anglaise, não foi feita para ser ouvida - para ser transmitida no rádio, por exemplo -, mas realizada no contexto de um arquivamento sistemático das atividades do teatro. Não se ouve o espetáculo, mas uma apresentação do espetáculo, com o público incluso, com vozes às vezes mal reproduzidas e com barulhos que se pode julgar parasitas. É isso que constitui, ao mesmo tempo, a riqueza e a dificuldade de escuta de um tal vestígio. Sua riqueza é única: ela é a memória do evento teatral na sua totalidade, captado no seu ritmo e sua densidade própria. A dificuldade técnica, quanto a ela, não é inultrapassável: o pesquisador pode escutar com fones de ouvido uma gravação que, na maioria das vezes, se apresenta sob a forma de um documento digital. Ele pode ouvir diversas vezes a mesma sequência, consultar o texto, os documentos complementares e, se o passado náo estiver longe demais, fazer, como nós o fizemos, apelo ao ouvido dos que viveram diretamente o evento.

O outro problema é mais delicado; trata-se na verdade de uma variação complexa daquele apontado por Alain Corbin. A tentação 
é grande, para um pesquisador em estudos teatrais, de fundar sua escuta de um espetáculo do passado nos desenvolvimentos ulteriores da arte do diretor e, sobretudo, nas ideias e imagens que ele pode ter do espetáculo a partir do discurso desse diretor, do texto, de fotografias, de relatos, de estudos existentes e de toda a memória difusa do evento. Ouvir o som desse evento pode produzir um efeito estranho, pois essa memória - que Claude Régy afirma constituir tanto o espetáculo quanto o momento preciso da apresentação ${ }^{40}-$ se encontra de repente confrontada a um vestígio de uma outra natureza, que náo é mais verdadeira, mas diferentemente verdadeira. Salvo exceçóes, nossa memória teatral coletiva é texto-visual e muito pouco sonora. Levar em consideração a dimensão auditiva da experiência pode completar e afinar uma abordagem da cena que permanece, principalmente, fundada sobre o olhar. Quando nos interessamos pelas vozes, por exemplo, é geralmente dentro de um espaço que é esse do olhar, acusticamente abstrato. A primeiríssima função dos documentos sonoros é proporcionar essa tomada de consciência de que o espaço sonoro é de uma natureza diferente do espaço visual. Essa consciência, levada a sério, leva a repensar os modelos teóricos e os métodos usuais da teatrologia e, consequentemente, os estudos genéticos. No caso de L'Amante Anglaise, ela leva a repensar a natureza e o espaço do que chamamos de imaginário, que se encontra no centro mesmo do processo de criaçáo e que modifica de maneira náo negligenciável a reconstituição da gênese do espetáculo.

\section{As Diferentes Contribuiçóes dos Documentos Sonoros ao Es- tudo Existente}

I

A gravação datada do início do ano de 1969 permite verificar qual texto foi efetivamente à cena na criação da peça. Encontra-se nela, por exemplo, a confirmaçáo de uma hipótese importante. Marguerite Duras, como se sabe, retrabalhava incessantemente sua obra. No anúncio gravado que abre o espetáculo, e que é idêntico nas duas gravaçóes, audível no documento correspondente à trilha sonora, do qual se pode ouvir diferentes versóes e diferentes tentativas feitas por François Périer e conservadas numa fita por um técnico, o ano do crime é 1966, em vez de 1949, data escrita no texto do TNP e enviada para a impressão um pouco antes do fim dos ensaios. Assim, a partir da estreia, a data era 1966. Essa correção importante para a interpretação do texto foi decidida nas últimas sessôes de trabalho. 
As duas gravaçôes das apresentações nos informam sobre as reaçóes do público. Claude Régy nota, em Espaces Perdus, que, em 1989, ouve-se L'Amante Anglaise "religiosamente, como um trio de música clássica" ${ }^{\text {"11 }}$. Não era o caso em 1969. A escuta grave, totalmente silenciosa, surge sobre um fundo impuro. No primeiro interrogatório, as respostas de Pierre Lannes, tanto com Servais como com Dauphin, suscitam risos. Suas duas vozes, com um tom sedutor e popular, bem conhecidas na época graças ao cinema, são também vozes de imitadores e cômicos, nas quais o engraçado aflora. $\mathrm{Na}$ parte II, durante o interrogatório de Claire Lannes, também se ri com frequência. Claude Régy nos disse em 2005 que havia ali um tom "boulevard". Tendo interpretado Feydeau, "Madeleine Renaud possuía esse famoso 'natural', extraordinário, aliás. Mas ela tinha também este instinto que a conduzia a algo do qual ela mesma não tinha consciência, eu acho". A voz e a atuação de Madeleine Renaud apresentam com efeito múltiplas variaçóes, de acordo com seus papéis sucessivos: a ingênua, a amorosa, a coquete de Marivaux ou das comédias leves e, de repente, Winnie de Dias Felizes, que ela havia interpretado dois anos antes com direção de Roger Blin. Às vezes, ela mostrava, também, um lado Arletty $^{42}$, insolente. As leituras unívocas, unicamente trágicas de peça, não resistem à escuta do arquivo. Em 1968-1969, o espetáculo encontra sua força nessas discrepâncias. Como lembra Claude Régy no texto de abertura de Espaces Perdus: "Essa mulher de pé não é nada, é todo mundo, qualquer um". Ele acrescenta: "O teatro náo é puro. Ele não é nem sagrado nem profano. [...]. O que importa, é a passagem. Nunca se deveria ver outra coisa no teatro além disto: o invisível movimento dessa passagem, mas incessantemente perpetuado". O que a gravação sonora do espetáculo nos deixa ouvir é exatamente uma passagem: entre o primeiro interrogatório e o segundo, passa-se de um teatro a um outro, mas sutilmente, náo há impureza antes e pureza depois. O interrogador, que é também o fabricante preciso dos silêncios, é a figura permanente desse espetáculo no qual o que ainda é um teatro do ver - e do voyeurismo - se transforma em um teatro de escuta - que acabará ele mesmo atingindo seus limites.

III

As gravaçôes sonoras das apresentações permitem escutar efetivamente a gênese de um teatro 'de escuta'. Os pesquisadores já discorreram sobre a "força sugestiva das palavras nas imagens cênicas", da "escrita como experiência sendo feita" (Sabine Quiriconi). Da "primazia da 
dicção sobre a ação e a ficçáo", do "espaço mental" (Arnaud Rykner) ${ }^{43}$. $\mathrm{O}$ arquivo sonoro permite compreender que os termos geralmente utilizados para evocar "a primazia da dicçáo" ainda fazem muita referência à visão, inclusive Claude Régy, ele mesmo, durante muito tempo não escapou do poder do modelo visual no conjunto do pensamento teatral moderno. Em março de 1969, em L'Avant-scène, ele fala de "um espetáculo de voyeurs" e utiliza a metáfora do microscópio. Em 1982, em um texto chamado De muito longe, de dentro, ele explica que os espectadores "viam: os espectadores viam a casa, viam o jardim, viam o marido, tudo isso com uma precisáo extraordinária”. Nós decidimos retomar então, esse imaginário que, na obra de Régy, deveria se substituir às imagens cênicas. Maryvone Saison trabalhou sobre essa questáo, sobre a noção de "palavra-imagem" que não é uma palavra criando imagem ${ }^{44}$. Ela evocava criaçóes mais recentes. A escuta do registro sonoro, que coloca em valor o dispositivo acústico esquecido, leva a crer que, já desde L'Amante Anglaise, emerge a questáo da adequaçáo do discurso crítico ao que se passa na sala Gémier. Régy falava de "diafrágma" (fotográfico) em relação à cortina metálica que, nessa sala, podia diminuir lateralmente a abertura da cena, deixando passar Madeleine Renaud. Arnaud Rykner insiste sobre o significado desse momento: "nada a ver". O barulho audível, violento, do fechamento da porta ressalta - talvez um pouco grosseiramente - que o teatro se reduziu definitivamente ao espaço que é normalmente o do público. Para Rykner, entra-se, então, em um "espaço ilimitado que lembra o espaço radiofônico". O teatro de Duras, como o de Beckett, pertence com efeito a uma época de criação marcada pelo rádio, pelas "paisagens mentais" infinitas da criação radiofônica. Mas, o que surpreende na gravação sonora, não é o ilimitado, mas a densidade acústica do espaço palco-plateia no qual o palco está na plateia. Já se falou muito do caráter indeciso do dispositivo dramático da escuta: o interrogador é um policial? Um juiz? Um psiquiatra, um psicanalista? Michael Lonsdale insiste muito sobre o que o encantava: ele não era ninguém. No entanto, o ponto comum dessas hipóteses é o espaço-tempo estreito, limitado que elas supóem. O microfone dos técnicos que fixa o som da apresentaçáo funciona, então, como uma lupa acústica, ele amplifica essa sensação de asfixia: todos os movimentos e reaçóes dos espectadores se ouvem e o texto, embora conhecido, soa diferentemente, como, por exemplo, no célebre trecho que nos comoveu de novo durante as escutas com o ator e diretor: "No jardim, você sabe, senhor, eu tinha uma barra de chumbo sobre a minha cabeça [...]". 
A gravação sonora leva a estudar, além do aspecto vocal, a gênese de uma oralidade. Reduz-se, geralmente, a dimensão sonora do teatro ao estudo das vozes. Escolhidas aqui por Marguerite Duras que escreve para elas, as duas vozes célebres de Madeleine Renaud e Michael Lonsdale merecem, com efeito, comentários, mas o que as gravaçóes permitem ouvir, na perenidade, é a gênese de uma forma de oralida$d e$, no sentido dado pelo último Paul Zumthor (1994): performada, eventualmente mediatizada, engajando uma auralidade socialmente significativa, na medida em que ela se torna significante no evento, mas também porque esse evento é estruturalmente linguajar.

Ouve-se, primeiro, na voz de Madeleine Renaud, uma série de vozes teatrais, de estratos de dicçóes, de sotaques: ela brinca, e Michael Lonsdale é cúmplice nesse jogo, nesse teatro de A Amante Inglesa. Sabine Quiriconi fala, por exemplo, da "empatia" criada por Duras no texto entre as vozes dos dois personagens, antes do deslocamento físico final do Interrogador que se aproxima de Claire até lhe tocar a cabeça. Essa empatia pode ser ouvida no documento, ela corresponde a uma cumplicidade entre atores que parecem brincar como crianças. Mas, progressivamente, a voz de Madeleine Renaud muda, o registro da oralidade muda, ela não atua mais, ela não dialoga mais, ela tenta contar, o ritmo da fonação se modifica (Bob Wilson disse admirar o "timing" da dicção da atriz em Dias Felizes). É a oralidade, dessa vez com o sentido proposto por Henri Meschonnic em $1982^{45}$, a oralidade do escrito, que teria repassado do texto à sua oralização sonora. "Aparentemente excluído, o teatro reaparece. É a escrita. É primitivo e sem limites. É uma outra palavra"4t6.

O diretor evoca aqui a revolução realizada por Duras entre Les Viaducs e L'Amante Anglaise $\mathrm{O}$ documento sonoro nos permite ouvir que o mesmo processo se reproduz, e se intensifica, do início ao fim do segundo interrogatório: alguém começa a falar, encontra, às vezes, seu ritmo. Helga Finter, falando de uma maneira geral da arte de Claude Régy, evoca "algo como a origem da linguagem" 47. Num tal teatro, o que as palavras "tornam visível" tem muito menos importância do que esse evento, fixado duas vezes, na fita magnética: a passagem audível ao ritmo quase sempre vivo do diálogo, depois a um outro ritmo, mais lento, preciso, difícil, e que parece esgotar, momentaneamente ao menos, todo o diálogo. 


\section{Notas}

${ }^{1}$ Este texto foi originalmente publicado em Grésillon, Almuth; Mervant-Roux, MarieMadeleine; Budor, Dominique (Org.). Genèses Théâtrales. Paris: CNRS éditions, 2010, p. 211-232. Ao final, Marie-Madeleine Mervant-Roux incluiu um anexo inédito sobre as gravaçóes do espetáculo, que aparece após as conclusôes para respeitar a cronologia do texto. $\mathrm{O}$ anexo data de 2013.

${ }^{2}$ Gostaríamos de expressar nosso grande reconhecimento a Michael Lonsdale, que nos emprestou e nos autorizou a reproduzir alguns extratos de seu exemplar do romance. Nós lhe devemos também a precisão de que a expressão "borrão magnífico" é de Marguerite Duras.

${ }^{3}$ Ver Claude Régy, v. 23, M.-M. Mervant-Roux (Org.), Paris, CNRS éditions, col. "Arts du spectacle/ Les voies de la création théâtrale", 2008, em particular os estudos de Chantal Guinebault-Szlamowicz, Sabine Quiriconi e Arnaud Rykner.

${ }^{4}$ Edição cujo título é significativo: Le théâtre de l'Amante anglaise (Gallimard, "L'Imaginaire").

${ }^{5}$ Agradecemos os responsáveis do IMEC e, particularmente, Albert Dichy por nos ter permitido consultar os documentos de gênese de L'Amante Anglaise e por ter facilitado e autorizado as reproduçóes.

${ }^{6} \mathrm{~N}$. T.: Catálogo on line do INA (Institut national de l'audiovisuel).

${ }^{7}$ Nossos agradecimentos a Jean Mascolo, assim como a Michèle Kastner que nos permitiram consultar esses arquivos.

${ }^{8}$ Para a referência das principais entrevistas publicadas ou gravadas, ver Claude Régy, 2008, bibliografia e filmografia.

${ }^{9}$ M. Lonsdale, em entrevista com Almuth Grésillon e Marie-Madeleine Mervant-Roux, Paris, 31 de março de 2005 - C. Régy, em entrevista com A. Grésillon e M.-M. MervantRoux, Paris, 15 de março de 2005. Agradecemos aqui aos dois.

${ }^{10}$ Sobre o caminhar frágil de Madeleine Renaud, ver C. Guinebault-Szlamowicz, 2008, p. 35.

${ }^{11}$ Depois da publicação desse estudo, em 2010, as gravaçôes sonoras, em fita magnética, de duas apresentações do espetáculo na sua criação (22 de fevereiro e 21 de dezembro de 1969) foram encontradas. Elas são analisadas no texto anexo que se encontra ao final deste artigo.

${ }^{12}$ Loleh Bellon fascinava Duras. Sabe-se que existe uma relação entre L'Amante Anglaise e Lol V Stein, daí a hipótese segundo a qual a amante do romance seria uma espécie de reprise de Lol ou de Catherine de La Bête dans la jungle, que interpretava a jovem atriz.

${ }^{13}$ Jean Schuster era, junto com Dionys Mascolo, responsável pela revista 14 juillet.

${ }_{14}$ A espessura temporal do "borrão" é devida ao fato de que Lonsdale atuou na peça de 1968 a 1989.

${ }^{15}$ O papel de Pierre Lannes será interpretado por Claude Dauphin ou Jean Servais (em alternância) e, a partir de 1982, por Pierre Dux. 
${ }^{16}$ N. T.: no original em francês são vinte palavras.

${ }^{17}$ N. T.: no original em francês são oito palavras.

${ }^{18}$ Numa versão ulterior - montada por Régy no Théâtre du Rond-Point em 1982 - Duras tentou reintroduzir provisoriamente a primeira parte sobre o personagem Robert Lamy, patrão do bar, interpretado por Jean-Marie Patte.

${ }_{19}$ A palavra se refere aqui a uma atividade mental mais complexa do que um simples imaginário compensador. Ver M.-M. Mervant-Roux, "Exercices méditatifs", em Claude Régy, 2008, p. 346-363.

${ }^{20}$ Bertrand Poirot-Delpech, num artigo elogioso, qualifica essa expressão de "jargão que está na moda" (Le Monde, 20 de dezembro de 1968).

${ }^{21}$ Ver Elie Konigson, "Les objets de représentation au théâtre (XVe -XVII ${ }^{\mathrm{e}}$ siècles), em Nouvelle Revue du Seizième siècle”, 1996, n. 14/2, p. 189-199.

${ }^{22}$ Duras o anota primeiro de maneira manuscrita abaixo da página 79 do "borrão", depois o passa a limpo numa folha separada que será inserida ao lado da página 78.

${ }^{23}$ N. T.: em francês as palavras "l'amante" [lamãt] e "la menthe" [la mãt] são homófonas.

${ }^{24}$ N. T.: em francês a palavra "anglaise" [ãglız] e a expressão "en glaise" [ã glız] (na terra) são homófonas.

${ }^{25}$ N. T.: em francês, as palavras "menthe", [mãt] "amante", [amãt] "plante" [plãt] rimam.

${ }^{26}$ N. T.: em francês, as palavras "banc" [bã] e "ciment" [sima] rimam.

${ }^{27}$ N. T.: em francês "ciment". A segunda sílaba "ment" é homógrafa à palavra "ment", (verbo mentir, $3^{\circ}$ pessoa do singular).

${ }^{28}$ N. T.: em francês, "qui ment?".

${ }^{29}$ N. T.: Em francês "bouillie”.

${ }^{30}$ N. T.: Em francês "grouillis".

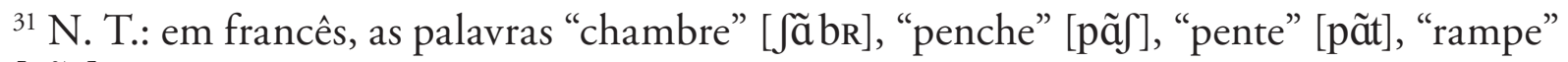
[Rãp] são assonantes.

32 “[E]la [Claire / Madeleine Renaud] se afasta para tão longe que nós a perdemos, e então ela se encontra. [...] Trazida por asas indiscerníveis, ela viajou do outro lado” C. Régy, Espaces perdus, Plon, 1991, p. 14.

${ }^{33}$ Régy (2008), em entrevista com A. Grésillon e M.-M Mervant-Roux.

${ }^{34}$ Este texto foi incluído por M. M. Mervant-Roux como anexo ao artigo. Ele não foi publicado em francês.

35 N. T.: Théâtre National Popular, fundado em 1920 em Paris por Firmin Gémier, atualmente Théatre National de Chaillot.

${ }^{36}$ Sobre essas questões, ver meu estudo: "Peut-on entendre Sarah Bernhardt? Le piège des archives audio et le besoin de protocoles", In: Sociétés et représentations, número 35, Archives et patrimoines visuels et sonores, dirigido por Evelyne Cohen e Marie-France Chambat- 
Houillon, Paris, CREDHESS, n. 35, p. 165-182, 2013. Ver também o número triplo da revista Théâtre/Public apresentando os trabalhos do grupo ARIAS-CNRS/CRI de Montreal, org. Jean-Marc Larrue, M.-M. Mervant-Roux: Le son du théâtre, 1 (Le passé audible, n. 197), 2 (Dire l'acoustique, n. 199) e 3 (Voix, Words, words, words), n. 201, Gennevilliers, 2010-2011.

37 Jonathan Sterne, The Audible Past. Cultural Origins of Sound Reproduction [2003], $3^{\mathrm{e}}$ edição, Durham et Londres, Duke University Press, 2006, p. 19.

${ }^{38}$ Daniel Deshays, Pour une écriture du son, Kincksieck, 2006, p. 45.

${ }^{39}$ Alain Corbin, Les Cloches de la terre. Paysage et culture sensible dans les campagnes au XIXe siècle, Flammarion, "Champs" [Albin Michel, 1994] 2006, p. 14.

40 Ver por exemplo Claude Régy, "Déconstruction", em Claude Régy, "Les voies de la création théâtrale", v. 23, M.-M. Mervant-Roux (Org.), Paris, CNRS Éditions, col. "Arts du spectacle", 2008, p. 14-19.

${ }^{41}$ Claude Régy, Espaces perdus, Plon, 1991, p. 56.

${ }^{42}$ N. T.: Atriz francesa (1898-1992).

${ }^{43}$ Ver os estudos respectivos em Claude Régy, 2008, p. 136-175 e p. 52-65.

${ }^{44}$ Ver seu estudo, em Claude Régy, 2008, p. 116.

${ }^{45}$ Henri Meschonnic, "Qu'entendez-vous par oralité ?", in: Langue française, n. 56, 1982, p. 6-23.

${ }^{46}$ Claude Régy, Espaces perdus, 1991, p. 17.

47 Ver seu estudo em Claude Régy, 2008, p. 295.

\section{Referências}

CORBIN, Alain. Les Cloches de la Terre. Paysage et culture sensible dans les campagnes au XIXe siècle. Flammarion, "Champs" [Albin Michel, 1994] 2006.

DESHAYS, Daniel. Pour une écriture du son. Paris: Kincksieck, 2006.

DURAS, Marguerite. L'Amante Anglaise. Paris: Gallimard, 1967.

DURAS, Marguerite. Le Théâtre de l'Amante Anglaise. Paris: Gallimard, 1991.

GUINEBAULT-SZLAMOWICZ, Chantal. La quête de l'espace mental. In: MERVANTROUX, Marie-Madeleine (Org.). Claude Régy. Paris: CNRS éditions, 2008. P. 24-51. (Coleção Arts du spectacle/Les voies de la création théâtrale, v. 23).

KONIGSON, Elie. Les Objets de Représentation au Théâtre (XVe-XVII siècles). Nouvelle Revue du Seizième siècle, Paris, n.14/2, p. 189-199, 1996.

LONSDALE, Michael. Visites. Paris: Fayard, 2012.

MERVANT-ROUX, Marie-Madeleine (Org.). Claude Régy. Paris: CNRS éditions, 2008. (Coleção Arts du spectacle/Les voies de la création théâtrale, v. 23).

MERVANT-ROUX, Marie-Madeleine. Peut-on Entendre Sarah Bernhardt ? Le piège des 
archives audio et le besoin de protocoles. In: COHEN, Evelyne; CHAMBAT-HOUILLON, Marie-France (Org.). Sociétés et Représentations, Paris, CREDHESS, n. 35, p. 165-182, 2013.

MERVANT-ROUX, Marie-Madeleine; LARRUE, Jean-Marc (Org.). Le Son du Théâtre 1. Le Passé Audible. Théâtre/Public, Gennevilliers, n. 197, p. 2-106, out. 2010.

MERVANT-ROUX, Marie-Madeleine; LARRUE, Jean-Marc; BOVET, Jeanne (Org.). Le Son du Théâtre 3. Voix, Words, Words, Words. Théâtre/Public, Gennevilliers, n. 201, set. 2011.

MERVANT-ROUX, Marie-Madeleine; LARRUE, Jean-Marc; GUINEBAULT-SZLAMOWICZ, Chantal (Org.). Le Son du Théâtre 2. Dire l'Acoustique. Théâtre/Public, Gennevilliers, n. 199, p. 1-110, mar. 2011.

MESCHONNIC, Henri. Qu'entendez-vous par oralité ?. Langue Française, Paris, n. 56, p. 6-23, 1982,

POIROT-DELPECH, Bertrand. Le Monde, Paris, 20 dez. 1968.

QUIRICONI, Sabine. Visages du Monologue. In: MERVANT-ROUX, Marie-Madeleine (Org.). Claude Régy. Paris: CNRS éditions, 2008. P. 136-175. (Coleção Arts du spectacle/ Les voies de la création théâtrale, v. 23).

RÉGY, Claude. Déconstruction. In: MERVANT-ROUX, Marie-Madeleine (Org.). Claude Régy. Paris: CNRS éditions, 2008. P. 14-19. (Coleção Arts du spectacle/Les voies de la création théâtrale, v. 23).

RÉGY, Claude. Espaces Perdus. Paris: Plon, 1991.

RYKNER, Arnaud. L'Inconnu de la Chambre Noire. Claude régy et les dispositifs. In: MERVANT-ROUX, Marie-Madeleine (Org.). Claude Régy. Paris: ediçóes do CNRS, 2008. (Coleção Arts du spectacle/Les voies de la création théâtrale, v. 23).

STERNE, Jonathan. The Audible Past. Cultural Origins of Sound Reproduction [2003]. 3. ed. Durham et Londres: Duke University Press, 2006.

Almuth Grésillon estudou literatura na Alemanha e linguística na França. É doutora na área e uma das pioneiras da Genética Teatral na França. É pesquisadora do CNRS desde 1972. É autora de diversas obras na França e no exterior.

E-mail: Almuth.Gresillon@ens.fr

Marie-Madeleine Mervant-Roux é pesquisadora do CNRS na área de Estudos Teatrais. Ela coordena desde 2008 com Jean-Marc Larrue, no CRIalt, em Montréal, um projeto internacional sobre $O$ Som no Teatro (séculos XIX-XXI). É uma das pioneiras da Genética Teatral e tem diversas publicaçóes na França e no exterior.

E-mail: marie-madeleine.mervant-roux@cnrs.fr

Recebido em 24 de janeiro de 2013 Aprovado em 26 de fevereiro de 2013 